Old Dominion University

ODU Digital Commons

Counseling \& Human Services Theses \&

Dissertations

Spring 2011

\title{
The Preparation of Master's Level Professional Counselors for Positions in College and University Counseling Centers
}

Brian M. Shaw

Old Dominion University

Follow this and additional works at: https://digitalcommons.odu.edu/chs_etds

Part of the Counseling Psychology Commons, Counselor Education Commons, and the Higher Education Commons

\section{Recommended Citation}

Shaw, Brian M.. "The Preparation of Master's Level Professional Counselors for Positions in College and University Counseling Centers" (2011). Doctor of Philosophy (PhD), Dissertation, Counseling \& Human Services, Old Dominion University, DOI: 10.25777/xgfh-ym47

https://digitalcommons.odu.edu/chs_etds/91

This Dissertation is brought to you for free and open access by the Counseling \& Human Services at ODU Digital Commons. It has been accepted for inclusion in Counseling \& Human Services Theses \& Dissertations by an authorized administrator of ODU Digital Commons. For more information, please contact digitalcommons@odu.edu. 
THE PREPARATION OF MASTER'S LEVEL PROFESSIONAL COUNSELORS FOR POSITIONS IN COLLEGE AND UNIVERSITY COUNSELING CENTERS

by

Brian M Shaw

B S , December 1997, North Carolına State Unıversity

M A, May 2008, Wake Forest Unıversity

A Dissertation Submitted to the Graduate Faculty of Old Dominion University

in Partial Fulfillment of the

Requirements for the Degree of

DOCTOR OF PHILOSOPHY

COUNSELING

OLD DOMINION UNIVERSITY

May 2011

Approveajoy

Theodore P Remley, Jr (dhair)

Chrstıne Ward (Axemher)

AłamSchwitzer (Member)

Dana Burnett (Membër) 


\begin{abstract}
THE PREPARATION OF MASTER'S LEVEL PROFESSIONAL COUNSELORS FOR POSITIONS IN COLLEGE AND UNIVERSITY COUNSELING CENTERS
\end{abstract}

\author{
Brian M Shaw \\ Old Dominion University, 2011 \\ Director Dr Theodore P Remley, Jr
}

College and university counselors are tasked with performing a multitude of roles and meetıng a variety of client needs unique from other counselıng settıngs It is important to examıne the ability of counselors who work in these settings to determine if they have been adequately prepared This study investigated the adequacy of preparation of entry-level master's level professional counselors for work in college and university counselıng centers Adequacy of preparatıon was examıned by surveying college and university counseling center directors about their perceptions regarding the ability of entry-level master's level professional counselors to perform specific roles and meet relevant client needs in college and university counseling centers 


\section{ACKNOWLEDGEMENTS}

To Dr. Ted Remley: You have gone above and beyond in your support of me in my $\mathrm{Ph} \mathrm{D}$ journey It has been greatly appreciated

To Drs. Christine Ward, Alan Schwitzer, and Dana Burnett: Thank you for your many hours of service as members of my dissertation committee, and for your helpful feedback each step of the way

To my famıly and friends: Thank you for your support and patience of my journey over the years I promise this is my last degree 


\section{TABLE OF CONTENTS}

ABSTRACT

11

ACKNOWLEDGEMENTS ..............................................................................................

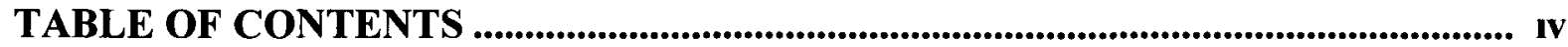

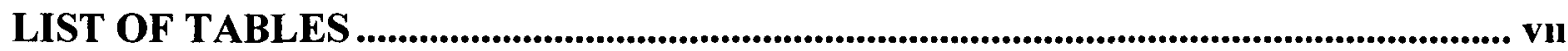

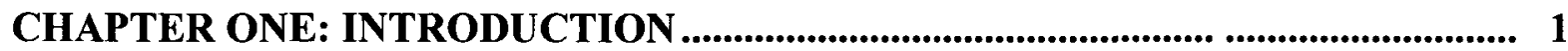

Background 11

$\begin{array}{ll}\text { Purpose of the Study } & 3\end{array}$

Significance of the Study

Research Questions

$\begin{array}{lr}\text { Limitations and Delimitations } & 6\end{array}$

$\begin{array}{ll}\text { Assumptions of the Study } & 7\end{array}$

$\begin{array}{lr}\text { Definitions of Terms } & 7\end{array}$

CHAPTER TWO: REVIEW OF THE LITERATURE........................................... 9

$\begin{array}{lr}\text { Introduction } & 9\end{array}$

Roles and Functions of College and University Counselıng Centers 9

$\begin{array}{ll}\text { The Needs and Problems of Students } & 11\end{array}$

$\begin{array}{ll}\text { Emerging Trends and Issues } & 12\end{array}$

CHAPTER THREE: METHODOLOGY ........................................................................ 23

$\begin{array}{lr}\text { Purpose Statement } & 23\end{array}$

$\begin{array}{ll}\text { Research Desıgn } & 24\end{array}$

$\begin{array}{ll}\text { Research Questions } & 24\end{array}$

$\begin{array}{ll}\text { Participants } & 25\end{array}$ 
Instrumentation

$\begin{array}{ll}\text { Item Generation and Content Validation } & 28\end{array}$

$\begin{array}{ll}\text { Procedures } & 29\end{array}$

$\begin{array}{ll}\text { Data Analysis } & 30\end{array}$

$\begin{array}{ll}\text { Limitations } & 32\end{array}$

$\begin{array}{ll}\text { Strengths of Study } & 33\end{array}$

Summary of Methodology $\quad 33$

CHAPTER FOUR: RESULTS .............................................................................. 34

Prelımınary Data Screenıng and Provısıon of Varıables 34

Descriptıve Data for Partıcıpants and Institutıons Represented 35

$\begin{array}{ll}\text { Evaluation of Instrument } & 42\end{array}$

$\begin{array}{ll}\text { Research Question } 1 & 46\end{array}$

Research Question 2

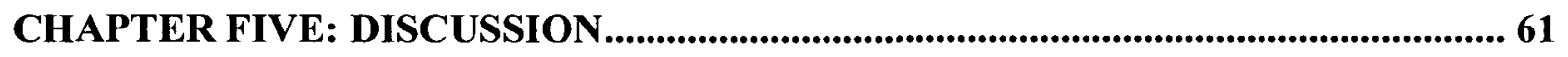

$\begin{array}{ll}\text { Summary of Findings } & 61\end{array}$

Implicatıons for College and Unıversıty Counselıng Center Clınıcal Supervisors 66

Implicatıons for College and Unıversity Counselıng Center Directors 66

Implicatıons for Master's Level Counselors and Counselor Traınees Seekıng

Employment in College and Unıversity Counselıng Centers $\quad 68$

Implications for Counselor Educators $\quad 69$

$\begin{array}{ll}\text { Limitations of Study } & 70\end{array}$

$\begin{array}{ll}\text { Suggestions for Future Research } & 73\end{array}$

$\begin{array}{ll}\text { Summary } & 74\end{array}$ 
Abstract

Introduction

Method

Results

Discussion

Table 1

Table 2

Table 3

References for Chapter Six

REFERENCES. 


\section{LIST OF TABLES}

Table 1 Experience Working with Master's Level Counselors

Table 2 Gender of Partıcıpants

Table 3 License Held by Participant

Table 4 Years of Experience

Table 5 State Where Institution Located

Table 6 Number of Enrolled Students

Table 7 Type of Institution

Table 8 Clınicians Employed

Table 9 Correlations Between Items and Identıfied Factors

Table 10 Frequencies of Overall Ratıng of Master's Level Counselors

Table 11 Descriptıve Statıstıcs for Overall Ratıng of Mental Health Professionals

Table 12 Ratıngs of Master's Level Counselors Ability to Meet Client Needs

Table 13 Ratıngs of Master's Level Counselors Abılity to Perform Roles

Table 14 Coefficients for Final Indırect Dutıes Model

Table 15 Coefficients for High Rısk Counselıng Model

Table 16 Coefficients for Low Risk Counselıng Model 


\section{CHAPTER ONE}

\section{INTRODUCTION}

\section{Background}

College and university counselıng centers have a rıch history stretching back into in the early 20th century As early as 1910, a mental hygiene clinic was created at Princeton University to attend to mental health concerns of students, spurred in part by Clifford Beers' 1908 publication, A Mind That Found Itself, about his experience with developıng a mental ıllness whıle an undergraduate student at Yale Unıversity (Farnsworth, 1957, Meadows, 2000) These early clınics were staffed primarıly by psychiatrısts They were aimed at preventıng student dropouts due to mental lllnesses and orıented toward serving as a primary prevention against the development of mental 1llnesses (Farnsworth, 1957, Prescott, 2008) During the early 1900s, helping students with academic and vocational needs was viewed primarily as the responsibility of faculty and adminıstrators (Meadows, 2000) One of the first universities that deviated from this practice was the University of Minnesota, which in 1932 established an educational and vocational counseling center as a separate unit within the university (Meadows, 2000)

During subsequent decades, college and university counselıng centers grew to play an increasing role in the provision of academic and vocational counseling, influenced significantly by the end of World War II when counselors were recruited to help provide returnıng veterans with educational and vocatıonal guidance (Meadows, 2000) By the 1950s, over half of colleges and universities in the U S had counselıng centers on their campuses, and counselıng became more recognized as a profession separate from student personnel work (Heppner \& Neal, 1983, Reınhold, 1991) 
In the decades of the $60 \mathrm{~s}$ and $70 \mathrm{~s}$, counseling centers incorporated more personal counseling into their services, and took on consultation and outreach roles (Heppner \& Neal, 1983) This expansion took place as a result of an 1deological shift that began to emphasized the role of counselors in primary prevention and their role as facilitators of institutional changes that could improve the learnıng environment for students (Heppner \& Neal, 1983, Meadows, 2000) Also durıng this perıd, counseling centers became less involved in providing vocational counseling, which has been attributed to both the increase in the role of personal counselıng and the creation of separate career centers on campuses (Heppner \& Neal, 1983)

In recent decades, counselıng centers have contınued to offer counseling to students for personal, academıc, and career needs (Pace, Stamler, Yarrıs, \& June, 1996, Stone \& Archer, 1990, Whiteley, Mahaffey, \& Geer, 1987) Staff from these centers have contınued to be involved in a variety of other functions including consultation with faculty and staff, assistıng with student affairs programmıng, involvement in retention efforts, and rısk assessment (Gallager, 2009) While indıvidual counselıng centers vary in services and scope, many counseling centers have contınued to trend away from academic and vocational counseling, and to focus more on personal counseling, consultation, and outreach (Archer \& Cooper, 1998, Cooper \& Archer, 2002, Gallagher, 2001, 2009, Heppner \& Neal, 1983, Stone \& Archer, 1990)

In 2009, there were 2,467 4-year degree grantıng universities or colleges in the U S with an enrollment of 9,677,408 students (National Center for Education Statistıcs, 2009) Most institutions in the US provide a counselıng center as part of the services offered to enrolled students (Whiteley, Mahaffey, \& Geer, 1987) 


\section{Purpose of the Study}

The purpose of this study was to investigate the adequacy of preparation of entrylevel master's level professional counselors for professional positions in college and university counseling centers For purposes of this study, master's level counselor refers to a mental health professional with a master's degree in counseling Preparation was assessed by surveying college and university counseling center directors' perceptions regardıng the ability of entry-level master's level counselors to meet client needs and perform specific roles The client needs and counselor roles listed in the survey instrument were based on exıstıng literature and standards regardıng college and university counselıng centers and clientele Additionally, preparation was investigated by obtaining an overall ratıng of the directors' perceptions of professional counselor preparation compared to other mental health professionals in the same settıng

\section{Significance of Study}

\section{Informing Counselor Traınıng}

The American Counseling Association Code of Ethics (ACA, 2005) exhorts counselors to "practice only within the boundaries of their competence, based on their education, trainıng, supervised experience, state and natıonal professional credentials, and appropriate professional experience" (p 9) Furthermore counselors workıng in specialty areas are supposed to obtain "appropriate education, trainıng, and supervised experienced" ( $p$ 9) related to that setting The Council for Accreditation of Counseling and Related Educational Programs (CACREP, 2009) has recognized college and university counselıng as a specialty area that has unıque trainıng needs that vary from other areas of counselıng It is important for counselor preparation programs to receive 
feedback that can inform changes to curricula that will help professional counselors to be adequately prepared for work in college and university counseling centers This need is made more acute by the multitude of roles college and university counselors serve and the unique and changing needs of the student population

\section{Informing Hiring Decisions of College and University Counseling Centers}

Historically, college and university counselıng centers have been staffed predominantly by doctoral level clinicians (Gallagher, 2009, Stone, Vespia, \& Kanz, 2000) Stone, Vespia, and Kanz (2000) found $94 \%$ of counselıng center staff members had a doctoral degree in counseling psychology or clinical psychology An annual survey of college and unıversity counselıng center directors (Gallagher, 2009) has also reflected the predominant employment of doctoral level psychologists as directors As more master's level counselors are trained for work in college and unıversity counseling centers it will be important to determine if they are adequately prepared for these roles An understanding of strengths and deficiencies of entry-level master's level counselors may help to guide hirıng decisıons and to identıfy areas where additional on-the-job trainıng may be needed

\section{Uncoverıng Differences Based on Director, Counselıng Center, and Institutional Factors}

As part of the study, information will be collectıng about directors, counseling centers, and the institutions they serve These characterıstıcs may help to illuminate how other variables have an impact on directors' perceptions of the preparation of master's level counselors For example, it may be that directors who are psychologists will rate entry-level master's degree counselors more poorly than directors who are counselors, or 
that directors of smaller institutıons will rate entry-level master's degree counselors higher than those at larger institutıons Additıonally, these observations may llumınate differences in the professional roles and client needs based on institutional characteristics For example, if professional counselors are perceived as less prepared for consulting in large institutions as opposed to small institutions, it may reflect that the role demands and client needs vary based on institutıonal size Thus, findings from the prelımınary study may provide a stımulus for future research that may better illuminate these differences

\section{Research Questions}

The primary research question of this study was How do college and university counseling center directors rate the preparatıon of entry-level master's level counselors for work as mental health professionals withın their centers? This question was explored by the sub-questions (1) How do directors' overall ratıngs of entry-level master's level counselors compare to overall ratıngs for other mental health professionals in similar positions? and (2) How do directors rate the abilities of entry-level master's level counselors to meet the needs of clients and perform specific tasks associated with mental health professionals in a college or university counseling center?

Additionally, this research project sought to answer the question To what extent do the credentials of the counseling center director, the number of years he or she has been a mental health professional, the number of years he or she has been a director, the size of the college or university, the number of full time mental health professionals employed by the counseling center, the proportion of counselors to other mental health professionals on staff, and whether the institution is public or private predict perceptions 
of the preparation of entry-level master's level counselors for work in college and university counseling centers?

\section{Limitatıons and Delımitatıons}

The sample used for this survey was college and university counseling center directors at 4-year higher education institutions in the U S that have on-campus housing Thus, the study may not be generalizable to college and university counselıng centers in other types of institutions, including 2-year colleges Additionally, due to the smaller relatıve prevalence of very large colleges and universitıes (greater than 20,000 students), a smaller number of these institutions in the sample may prevent generalizations to this group

The survey instrument measured the perception of counseling center directors towards mental health professionals Directors may have had little experience supervising partıcular credentıaled professionals, which may have impacted their ratıngs of those professionals

Moreover, directors may be biased in their ratings based on a few highly favorable or unfavorable experiences, or upon their most recent experiences Thus, ratıngs may not be an accurate representation of the preparation of the professional counselors as a whole

As the study examined directors' perceptions of the preparation of entry-level master's level professional counselors, the study did not reflect on the ability of doctoral level professional counselors or reflect upon the ability of professional counselors who have obtained additıonal on-the-job experience or contınuing education 


\section{Assumptions of the Study}

It was assumed that all partıcipants understood the instrument and rated items accurately and honestly with minımal influence from social desirability Additionally, it was assumed that there was a substantial correlation between the perception of preparation as rated by the directors and the actual level of preparation

\section{Definitions of Terms}

College or University Counseling A service unit of a college or university that Center provides counseling to students in support of personal, academic, and career concerns

\section{College or University Counselıng}

Center Director

Preparation

Entry-Level Master's level

Counselor
A person serving in either an adminıstratıve or

clinical supervisory role over mental health professionals in a college or university counselıng center

The quality of training through both academic coursework and practica and internship experiences in fulfillment of a degree as evaluated through the ability of mental health professionals to perform specific roles and meet client needs Not included is post-master's or post-doctoral experiences or training Person with a master's degree in counseling pursuing professional licensure, with no postmaster's experience or trainıng 
Credentials

Client Needs

Non-traditional Student
Qualifications for position, including educational background and license

Presentıng symptoms or concerns for which a

person may seek services from a counselıng

center

Students who are either not of the typical age of college, or are enrolled on a part-tıme basis Includes students who have delayed enrollment, are reenterıng college after later in life, or additıonally work full tıme jobs (Bean \& Metzner, 1985) 


\section{CHAPTER TWO}

\section{REVIEW OF THE LITERATURE}

\section{Introduction}

Exıstıng literature regardıng the roles and functions of college and university counselors will be discussed Literature will be reviewed related to the counseling needs and problems of students Emerging trends and issues facing college and university counseling centers, including the increasing call for accountability, will be discussed

\section{Roles and Functions of College and University Counseling Centers}

Two standards that have provided criteria for the assessment of college and university counselıng centers emerged in the 20th century and have shaped and guided the development of college and university counseling centers The standards of the International Association of Counseling Services (IACS, Boyd et al , 2003) and those developed by The Counsel for Advancement of Standards in Higher Education (CAS, 2009) IACS accredits college and university counseling centers and is "intended to advocate for quality counselıng services that contınue to perform effectıvely and to show awareness of and concern for professional growth" (IACS, 2010) Growing out of guidelınes first establıshed in 1971 and subsequently revised in 1981 and 2000, these standards delineate a range of requirements for accreditation including the roles and functions of counseling centers and the necessary qualıfications and training of staff (Boyd et al ) IACS standards state the following about the roles of college and university counseling centers

The most prominent is providing counseling and/or therapy to students experıencıng personal adjustment, vocational, developmental and/or psychological 
problems that require professional attention Second is the preventative role of assisting students in 1dentıfying and learning skills that will assist them in effectıvely meetıng their educational life goals The third role involves supportıng and enhancing the healthy growth and development of students through consultation and outreach to the campus community (Boyd et al ,2003, p 169)

Within these roles, IACS specifies the following functions that counseling centers are to provide (1) Individual and group counselıng/psychotherapy, which includes the ability to use assessment technıques including psychological tests and to adhere to ethical standards, (2) Crisis intervention and emergency services, (3) Outreach interventions, (4) Consultation interventıons, (5) Referral resources, (6) Research, (7) Program evaluation, and (8) Traınıng, which includes supervising staff who are completıng internshıp, residency, or post-doc trainıng (Boyd et al , 2003)

Simılarly, the CAS Standards (2009) emphasize that the mission of counseling centers is to assist students towards accomplıshing personal, academic, and career goals (p 179) This mission is to be accomplished through remedial counseling services, preventative/developmental outreach, and consultation with faculty and staff in the institution Counseling centers also are to provide assessment of students' needs and appropriate referrals when necessary (p 179) Specifically, counselıng centers are to provide the following (1) Individual counselıng, (2) Group interventions, (3) Psychological testıng, (4) Outreach efforts to address developmental needs and concerns of students, (5) Counselıng support to help students with educatıonal skills, (6) Psychiatric consultation, evaluation and support, (7) Crisis intervention and emergency coverage, and (8) Staff and faculty professional development (p 180) 
Research has largely supported the existence of these roles and functions, while also illuminatıng the range of importance and tıme given to each area Gallagher (2001) found that directors and vice presidents attached the most importance to counseling centers providıng individual counselıng, crisis intervention, consultıng with faculty and staff, and training DeStefano, Petersen, Skwerer, and Bickel (2001) simılarly found that direct personal counselıng and crisis intervention services are regarded as the most important functions of college and university counselıng centers Cooper and Archer's (2002) study found individual and group personal counselıng, consultation, and practicum and internship training to be of higher priority than academic and career counselıng In regard to tıme, Gallagher (2009) found that counseling center directors reported that their centers spent $807 \%$ of their time on personal counseling, $47 \%$ on academic counselıng, and only $28 \%$ on career counselıng (119\% was specified as other) Despite these findings, the roles and functions of counseling centers can vary significantly among institutıons, based in part on such factors as the size of the institution and whether the institution is public or private (DeStefano, Petersen, Skwerer, \& Bıckel, Stone, Vespia, \& Kanz, 2000, Vespia, 2007)

\section{The Needs and Problems of Students}

Bıshop, Gallagher, and Cohen (2000) outlıned four sources that provide information related to problems faced by college students (1) Data collected through the use of diagnostic systems such as the Missourı Diagnostıc Classification system developed specifically to assess student problems, or the more general Diagnostics and Statıstıcal Manual (DSM) for diagnosıng mental ıllness, (2) Data collected from self report problem checklists that clients complete, (3) Data banks and surveys, which gather 
information from multiple institutions, and (4) Results from needs assessments conducted for particular settings

From different combinations of these sources of data, a number of taxonomies have been created categorizıng problems college students face Chandler and Gallagher (1996) classified student problems into 13 areas Relationship difficulties, career uncertainty, self-esteem issues, existential concerns, academic concerns, depression, anxiety, eating disorders, substance abuse, sexual abuse or harassment, stress and psychosomatic symptoms, sexual dysfunction, and unusual behavior Grayson and Cauley (1989) categorized problems of college students into eight areas Sucidal ıdeatıon, famıly problems, relationships, depression and anxiety, academıc difficulties, substance abuse, sexual problems, and eatıng disorders As a final example, Robertson et al (2006) created a screenıng instrument for college and university counselıng center clients based in large part on existıng published and unpublished checklısts Through a factor analysıs, they ident1fied seven scales Mood Difficulties, Learning Problems, Food Concerns, Interpersonal Conflicts, Career Uncertainties, Self-Harm Indicators, and Substance/Addiction Issues

\section{Emerging Trends and Issues}

A number of trends and issues have been described as influencing college and university counselıng centers today including an increasingly diverse student population, an increasing severity of mental 1 llness on college campuses, complex legal and ethical ıssues, and a call for increased accountability of counseling services (Benshoff \& Bundy, 2000, Bishop, 2006) 


\section{Increasing Diversity of Student Body}

Colleges and universitıes have grown increasıngly diverse in recent decades, partly reflecting the increased diversity in the United States Examples of diversity include racial and cultural minorities, international students, nontraditıonal students, and openly gay and lesbian students (Chang, 1999) Thirty percent of the students who attend college are minorities and $44 \%$ are over the age of 25 (Choy, 2002) The number of international students in the U S has increased by $62 \%$ over a 20 -year period (Institute of International Education, 2006) In light of this increase in diversity, counseling centers are being called upon to be more multıculturally sensitıve, and to adjust services such that they are relevant and accessible to a demographically changing student population (e g , Benshoff \& Bundy, 2000, Bishop, 1990, Hodges, 2001, Stone \& Archer, 1990, Wright, 2000)

Meetıng the needs of a diverse student body presents multıple challenges For one, needs may vary significantly among populations For example, racial and cultural minorities are more likely to need support facing issues of discrimination and prejudice that may impede their academic or vocational goals (Lucas \& Berkel, 2005, Wright, 2000) Likewise, nontraditional students may need more support related to family issues or balancing work with school, while their developmental issues will also likely vary from those presented by younger students (Benshoff \& Bundy, 2000) Thus, increasing the multicultural competence and skılls of the staff and integratıng programmıng that targets needs of different populatıons becomes essentıal (Stone \& Archer, 1990) In support of the need for increased multıcultural knowledge and skills, a study by Smith et al (2007) found that increased multicultural trainıng was the primary way in which 
counselors reported that they could be better prepared for work in college and university counselıng centers

The underutılization of services is an additional concern facing college and university counselıng centers serving a demographically changing student population Lin (2000) found that international students underutılized counselıng services, potentially based on negative views of counseling or a lack of awareness of services Others have highlighted the difficulties faced by nontraditional students in accessing services that are avallable only during the day (Benshoff \& Bundy, 2000) Lack of utilization by different groups may require new strategies for counselıng centers, includıng alternatıve modes of counselıng such as peer-counselıng, extended hours, special walk-in hours, and a greater attention to outreach efforts (Lin, 2000, Stone \& Archer, 1990)

\section{Increasing Severity of Mental Illness on College Campuses}

Another issue that has gained significant attention has been related to the apparent increase in the severity of mental health issues of students (Bıshop, 2006, Sharkın \& Coulter, 2005) An often-cited source of supporting evidence of this increase is an annual survey of college and unıversity counselıng center directors (Gallagher, 2009) that has consistently reported a perception of the increase in severity of client problems In 2009, Gallagher reported that $934 \%$ of college and university counseling center directors surveyed perceived an increase in the number of students with severe psychological problems Another recent study that has supported this conclusion was by Benton, Robertson, Tseng, Newton, and Benton (2003) who compared the presentıng problems of college students over a 13-year tıme period and found an increase in 14 of 19 problem areas studied 
Others have claimed that there is insufficient evidence to support these claims Contradictory studies exıst that show only a small or insignificant increase in the severity of symptoms (e g , Cornısh, Komınars, Riva, McIntosh, \& Henderson, 2000, Hoeppner, Hoeppner, \& Campbell, 2009) The research methodology of the supportıng studies has also been questioned Sharf (1989) proposed that directors' perceptions may be biased based on a few difficult cases or by a desire to justıfy services in the face of threats to budget cuts from admınıstrators Additionally, Sharkın and Coulter (2005) cited the lack of consistent definitions and measures for severity that make drawing conclusions difficult

While the conclusions of this research is in debate, it is clear that severe cases of mental health issues are encountered by college counselors, including many disorders typically diagnosed in early adulthood (Gallagher, 2009, Kitzrow, 2003, Pledge, Lapan, Heppner, Kivlighan, \& Roehlke, 1998) While there is debate about the extent to which counseling centers can appropriately treat some disorders, at a minımum staff members in centers need to be able to competently assess, diagnose, and refer clients facing severe mental health 1ssues (G1lbert, 1992, Kitzrow, Sharkın \& Coulter, 2005)

\section{Legal and Ethical Challenges}

There are multıple legal and ethıcal challenges to providıng counselıng services withın college and university counseling centers Two primary areas where challenges arıse are in balancing emerging demands against admınıstratıve and budgetary constraints, and managing the conflicts of multiple roles and allegiances that the counseling centers serve within the institution (Bishop, 2006, Davenport, 2009) 


\section{Emerging Demands versus Admınistratıve and Budgetary Constraınts. With}

many institutional departments and services competıng for limited resources, counseling centers face budget constraints that may limit staffing (Gallagher, 2004) At the same tıme, counseling centers are called upon to provide services beyond direct client care, often including consultıng with faculty and staff, teaching, and coordınatıng other programs for the college or university Combined, these administratıve and budgetary pressures compel counselıng centers to make difficult decisions regardıng client care at the same tıme as demand for services is rising Counseling centers have responded by limitıng sessions of students, implementıng wait lists, and referring some students to community resources outside of the college or university (Bishop, 2006, Stone \& Archer, 1990) Each of these responses may create ethical and legal dilemmas for counseling center staff

Ethically, time limits on services may jeopardize the quality of care the center is able to provide, in particular in light of studies that have shown a positive correlation between number of sessions and client outcomes (e g, Draper, Jennıngs, Baron, Erdur, \& Shankar, 2003, Ghet1e, 2007) Moreover, others have argued that such limitations of counselıng centers make them inadequately equipped to treat severe psychopathology and called such efforts misguided kindness (Gllbert, 1992, p 695) Legally, colleges and universities have responsibilities to provide some accommodations and assistance to students with disabilities, including mental impairment disabilities, in accordance with the Rehabilitation Act of 1973, the Individuals with Disabilities Education Act (IDEA) of 1990, and the American with Disabilities Act of 1990 (Gibson, 2000, Prescott, 2008) Likewise, institutions may be in violation of the law by requiring a student to withdraw 
for mental health reasons (Hodges, 2001, Prescott, 2008) Thus, counselıng centers must account for multiple ethical and legal ıssues when makıng services decısions

Conflictıng Roles and Allegiances. By nature of being situated in and funded by colleges and universities, counselıng centers inherently serve conflictıng roles Far from a new phenomenon, Szasz (1967) called mental health workers in colleges double-agents serving both students and administrators In relation to students, counselors build alliances with students to help them face concerns and issues that may relate to professors and the institution At the same time, counseling centers may provide consultation to faculty and staff regarding problem students, and accept mandated referrals (Francis, 2000) These competıng allegiances have become more complex after the mass tragedies on campuses, such as the 2007 shootıngs at Virginia Tech In the wake of these events, there has been an increased pressure on college and university counseling centers to serve as homicidal prevention gatekeepers, with a focus on providing additional attention to screenıng for clients who may pose a risk to others on campus (Davenport, 2009, p 182)

These competıng roles are potentıally damaging to the essentıal student perception of trustworthıness necessary to attract students seekıng help (Davenport, 2009) Difficult issues are raised regarding the ethical concerns of confidentiality and dual relationships (Francis, 2000) Pressure to provide information and assistance to faculty and staff has to be carefully managed against the privacy rights of student clients Hayman and Covert (1986) reported confidentiality issues as the most frequently occurring ethical dilemma in college and unıversity counselıng centers Examples of potentıal dual relationships include a student who has previously worked in the counselıng center who is now seeking services, or a counselor who also teaches a class in 
which students who have been clients of the counseling center are enrolled (Francis, 2000)

Legal and ethical issues are raised as to the rights of parents of dependent children, who financially support their child's education and the services provided by the counseling center Parents of dependent students often do not understand why the confidentiality of the counselıng session is necessary (Bishop, 2006) Legally, counseling centers must adhere to the Family Educational Rights and Privacy Act (FERPA, Van Dusen, 2004), a law established to protect the privacy of student records At the same tıme, amendments to the law now allow for administrators to contact parents or others when necessary to protect the safety of the individual or of others, changes which have further complicated decisions between acting in the interest of safety and protecting individual privacy (Bishop, 2006, Heitzmann, 2008) Reflectıng a confusion among directors, a study by Gallagher (2004) showed directors were nearly split in their opinıon of whether it was legal to notıfy parents when a dependent student is hospitalized for mental health issues Nonetheless, while the obligation of educational institutions to notify parents is in debate, court decisions have consistently affirmed the institution's duty to ensure the short-term safety of students who they perceive at risk (Bishop, 2006, Prescott, 2008)

\section{A Call for Accountabılity}

In recent decades, counseling centers have come under increasing pressure to justıfy both the necessity and efficacy of services provided (Bıshop \& Trembley, 1987) These calls have come from admınıstrators wantıng to make informed budgetary and program decisions, scholars concerned about the ability of counseling centers to meet 
student needs, and from accreditation and standards bodies promoting the quality of service (Bishop \& Trembley, 1987) IACS standards (2000) state that university and college counselıng centers have a "responsibility to conduct ongoing evaluation and accountability research, to determine the effectiveness of its services, and to improve the quality of services" (p 5), while the Council for the Advancement of Standards for Higher Education (CAS, 2009) also require "systematic and regular research" (p 28) into the counseling services to evaluate whether "educational goals and the needs of students are being met" ( $\mathrm{p} 28$ ) Ongoing evaluation helps centers refine operations and adapt to new and changing aspects of college and university settıngs

Researchers have met this call for accountability in multiple ways including demonstratıng the effectıveness of treatment of mental health services offered by counselıng centers (e g, Minamı et al ,2009, Snell, Mallınckrodt, Hıll, \& Lambert, 2001, Vermeersch et al , 2004, Vonk \& Thyer, 1999, Wilson, Mason, \& Ewing, 1997) and linkıng the impact of counselıng services to institutional goals such as student retention, academic performance, and student adjustment (e g , Bell et al , 2009, Deroma, Leach, \& Leverett, 2009, DeStefano, Mellott, \& Petersen 2001, Dusseher, Dunn, Wang, Shelly, \& Whalen, 2005, Hınkelman \& Luzzo, 2007, Sharkın, 2004)

An area that has received less attention is an evaluation of the adequacy of preparation of mental health professionals who work in counseling centers Bishop (2006) raised this concern, noting a need for training programs to develop closer relationships with college and university counselıng centers in order to gain a better understandıng of skills and knowledge needed by professionals Bishop (2006) stressed 
the need for professionals to have training for the various roles that counselors are expected to serve including career and college development

While a number of studies exıst examınıng the trainıng and abılities of professional counselors, to date no studies have specifically examined the training of professionals who work in college and university counseling centers A study by Martı, Partın, and Trivette (1998) surveyed directors of mental health agencies in the state of Ohio in an effort to learn more about their perception of professional counselors Specifically, the survey asked directors to provide the number of Licensed Professional Counselors (LPCs) employed at the site, an overall ratıng of the ability of various mental health professionals, and a specific ratıng of the competence of LPCs in certain areas As part of the results, the authors reported on the statistical significance of the director's credentials related to his or her ratıngs of the abilities of mental health professionals at the site Martın, Partın, and Trivette (1998) found that social workers were rated highest, but that the majority of directors were also social workers

This study adopted the same strategy of surveying directors, however it was focused on the directors of college and university counselıng centers as opposed to mental health agencies The sample for the survey will be drawn from a natıonal sample of directors rather than from one state Focusing on a national sample of directors increased the potential of the results being more generalızable The study also utlized the general structure of Martın, Partın, and Trivette's (1998) survey by askıng directors about their overall ratıng of different credentıals as well as specifically more detalled questions about counselors While it would have been ideal to have directors provide detalled ratıngs on every type of credentialed mental health professional at a center, the length of 
the survey required would likely have resulted in a low return rate As an additional difference, this study targeted the directors' opinion of entry-level master's level counselors rather than that of all counselors This modification allowed the results to reflect more directly on the master's level training of counselors

Another study of relevance was conducted by McGlothlın and Davis (2004), who researched the perceived benefit of the Council for Accreditation of Counseling and Related Educational Programs (CACREP) core curriculum standards The sample for their survey study consisted of members of three associatıons the American Mental Health Counselors Association (AMHCA), the American School Counselor Association (ASCA), and the Association for Counselor Education and Supervision (ACES) The survey was constructed by using the verbatım text of the CACREP standards and asked participants to rate the benefit of each area to professional practice on a 4-point Likert scale Simılar to McGlothlın and Davis (2004), the questions in this study were based on existıng standards However, rather than using trainıng standards, this study focused on standards for college and university counseling centers, specifically the IACS and CAS standards By using these existıng standards in combination with published literature, the study was more hkely to be alıgned with practical skılls and knowledge needed by clinicians rather than theoretical standards developed for training programs

ACCA conducts an annual survey of college and university counselıng center directors in the U S (Gallagher, 2009) This survey collects demographic data about the directors of counseling centers and clients seen in addition to reportıng on admınıstratıve and clinical trends, but has not reported on perceptions of the preparation of staff The 
results of the Gallagher (2009) survey served as a point of comparison for the demographics and clinical trends of college and university counseling centers 


\section{CHAPTER THREE}

\section{METHODOLOGY}

This chapter explaıns the methodology used in the study The chapter is organized in the following order Purpose of the study, description of the research design, research questions, participant selection, instrumentation, data collection procedures, methods of data analysis, valıdity threats, and strengths of design

\section{Purpose Statement}

The purpose of this quantitatıve research study was to investigate the perceptions of college and university counseling center directors of the adequacy of preparation of entry-level master's level counselors for work in college and university counseling centers For purposes of this study, preparation was assessed by examınıng college and university counselıng center directors' ratıngs of the ability of entry-level master's level counselors to meet the needs of clients seeking services and perform duties associated with the work of counselors in this setting The directors' overall assessment of preparation and the mean value of scores from ratıngs of specific areas were the dependent variables of the study The independent variables in the study were the credentials of the counseling center director, the number of years he or she has been a mental health professional, the number of years he or she has been a director, the size of the college or university, the number of full time mental health professionals employed by the counseling center, the proportional number of counselors to other mental health professionals on staff, and whether the institution is public or private 


\section{Research Design}

A survey research study was conducted that collected information from college and university counseling center directors about their perceptions of mental health professionals typically employed in college and university counselıng centers

\section{Research Questions}

The following were the research questions in this study

1 How do college and university counseling center directors rate the preparation of entry-level master's level counselors for work as mental health professionals within their centers?

a How do directors' overall ratıngs of entry-level master's level counselors compare to overall ratıngs for other credentialed mental health professionals in similar positions?

b How do directors rate the abilities of entry-level master's level counselors to meet the needs of clients and perform specific tasks associated with mental health professionals in a college or university counseling center?

2 To what extent do the credentials of the counseling center director, the number of years he or she has been a mental health professional, the number of years he or she has been a director, the size of the college or university, the number of full time mental health professionals employed by the counseling center, the proportion of counselors to other mental health professionals on staff, and whether the institution is public or private predict perceptions of the preparation of entry-level master's level counselors for work in college and university counseling centers? 


\section{Participants}

The population used for the study was directors of counselıng centers at 4-year colleges and universities located in the U S which offered on-campus housing and had at least 1,000 students enrolled Colleges and universities without on-campus housing and those with less than 1,000 students were excluded based on the assumption that services offered would significantly vary from those offered to traditional campus communities

A list of colleges and universities in the U S was obtained by accessing an online database of the National Center for Education Statistics (NCES, 2009), a part of the U S Department of Education A search of 4-year institutions in the U S that grant bachelor's degrees resulted in 2,467 institutions This number closely matched the number of 4-year higher education institutes, 2,582, reported by the U S Census Bureau (2009) Elımınatıng colleges and universities without on-campus housing or with less than 1,000 enrolled students reduced the list to 1,325 institutions

An attempt was made to obtain email addresses for each director by searching the respective institution's web site and by contacting the counseling center and requestıng the email address by phone Institutions that did not report having a counseling center, that refused to provide an emall address, or whose emall was returned undeliverable, were excluded from the list of participants An initial pilot survey was submitted to 50 directors randomly selected from the population who were also excluded from the full study These exclusions reduced the list of participants solicited in the full study to 1,114 Assuming a medium effect size and $P=8$, at $\alpha=05$, a mınımum of 102 partıcipants were necessary for the full survey (Cohen, 1992) A total of 157 surveys were completed, fulfillıng the minımum participant requirement 


\section{Instrumentation}

The survey instrument contained 7 sections (Appendix A) The first section contained informed consent information and an indication of Institutional Review Board (IRB) approval The second section collected information about experiences participants have had working with master's-level professional counselors The third and fourth sections contained questions that evaluated the perceived ability of entry-level master's level counselors to meet specific client needs and perform specific tasks The fifth section asked for an overall ratıng of the perceived preparation of master's level counselors and other mental health professionals for work in college and university counselıng centers The sixth section collected demographic information about the director and information about the counseling center The seventh and optional section provided a place for participants to provide additional feedback in essay form regarding their perceptions of the preparation of master's-level counselors

\section{Informatıon About Experiences Working with Master's-Level Counselors}

Partıcıpants were asked to indicate experiences they have had workıng with master's level counselors This question was presented at the beginning of the instrument to increase the likelihood that all partıcıpants would answer

\section{Ratıng of Entry-Level Master's Level Counselors Ability to Perform Common}

\section{Tasks and Meet Client Needs}

This section was created based on personal experiences working in a university counseling center, a review of literature, and a review of exıstıng standards for college and university counseling centers Items were categorized as etther representıng a common task that a counselor would be expected to perform or specific needs of clients 
Partıcipants were asked to rate each item using a 6-point Likert scale $(1=$ very unprepared, $6=$ very prepared) Higher scores indicated a higher level of perceived abilities of counselors to complete tasks or meet client needs in a particular area Overall Rating of Entry-Level Master's Level Counselors and Other Mental Health Professionals

In additıon to ratıng entry-level master's level counselors on specıfic tasks and their ability to meet specific client needs, the survey included an overall ratıng of the perceived adequacy of preparation of various entry-level mental health professionals to meet client needs and fulfill relevant roles withın a college or university counselıng center Specifically, the survey asked participants to rate professional counselors, clinical social workers, marriage and famıly therapists, clınical psychologists, counselıng psychologists, psychiatrists, and rehabilitation counselors each on a 6-point Likert scale $(1=$ very unprepared, $6=$ very prepared $)$

\section{Demographic and Counselıng Center Information}

Participants were asked to provide information about themselves and the counseling center where they are employed Demographic information included the director's gender, mental health credentıals, the highest educatıonal degree obtained, the number of years of experience as a mental health professional, and the number of years the partıcipant has been employed as a college or university counseling center director Information on the counseling center included the number of mental health professionals employed, the size of the college or university served by the center, whether the institution is public or private, and the state where the institution is located 


\section{Item Generation and Content Valıdation}

For developing an instrument to rate the preparation of entry-level master's level counselors, peer-reviewed literature was used to uncover common tasks of college and university counselıng center mental health professionals and typical needs of clients that utılize their services Addıtıonally, exıstıng standards, includıng accredıtatıon standards that relate to tasks and client needs were also reviewed Based on findings and on discussions with committee members, an initial list of items was created

For establishing valıdity, this initial list of items was sent to an expert panel of college educators with expertise in college and university counseling These experts were asked to what extent the list of items is relevant to examining the preparation of master'slevel counselors for work in college and university counseling centers Specifically, experts were asked to indicate for each item whether it is Not at all, Somewhat, or A lot relevant Additionally, experts were asked to provide any additional items that they believe should be included in the instrument Of the five experts solicited, four returned completed reviews of the survey Three of the reviewers were male, and one female Experience of reviewers included research and publications related to college counseling, work experience in college and university counselıng centers, teachıng courses related to college counselıng, and supervising intern and practıcum students workıng in college and university counselıng centers

All questions were rated "A lot" or "Somewhat" relevant by reviewers, thus no questions were removed from the survey Based on the feedback, a new role related to Couples and Famıly Counselıng was added to Section III Additıonally, reviewers commented that some questions should be divided into two questions based on the 
content covered From Section II, Anger Issues and Risk of Harm to Others was divided into two questions and Identity Issues was divided into a question on Sexual Identity Issues and a question on Self-Concept Issues Similarly, in Section III the question regardıng Research was divided into two questions separatıng conductıng research from utllizing research Other changes included modifyıng the order and wording of some questions

Following the expert review, a pilot study was conducted with 50 participants Seven instruments were completed for a completion rate of $14 \%$ Item analysis was conducted on the 31 items from section II and section III of the instrument All tems had correlations greater than 50 except for one 1tem "Outreach" $(r=17)$ However, based on the low number of completed instruments in the analysis and a lack of a content difference between outreach and other items in the instrument, it was determined to leave the item in the instrument The coefficient alpha for the 31 items was 98

\section{Procedures}

All procedures and instrumentation were reviewed and approved by the Institutional Review Board (IRB) at Old Domınıon University An exemption for the research was obtained based on using survey procedures that protect the anonymity and confidentiality of partıcipants After approval of the study from the dissertation committee, emall messages were sent to counseling center directors The emall provided a request for the recipient to participate in the research along with a hyperlınk to the survey instrument hosted on SurveyMonkey (http //www surveymonkey com) SurveyMonkey did not reveal any information about the partıcipants other than the information collected through the instrument 
When partıcipants clicked on the website link, they were directed to the landıng page of the survey instrument This page presented more detalled information about the study, along with an informed consent statement Participants were informed that by choosing to contınue they indicated their consent to participate in the study Following clickıng to contınue, partıcıpants were guided through completıng the instrument The instrument provided ongoing information to partıcipants about the percentage of content remainıng At the end of the survey was a message thankıng partıcıpants for completing the survey and providing information on how they may contact the researcher or the committee chair to discuss questions or concerns, and to obtain access to the results of the study Reminder emals were sent out to the population group in order to increase the return rate As a feature of SurveyMonkey, participants were only able to complete the survey once based on the unique link sent by emall to individuals in the population

\section{Data Analysis}

As part of univariate data screening, SPSS Version 19 was used to report frequencies for all variables Data that were obviously erroneous were recoded as missing The remaining missing data was analyzed against demographic data to look for patterns of missing data that may distort findings Additionally, data was screened for outlers Outliers were omitted from the analysis using the listwise default if they represented less than $5 \%$ of the data If greater than $5 \%$ of the data were outlers mean substitution was used

Following data screening, a factor analysis was used to determine core factors present in the instrument Next, data analysis was conducted using descriptive statistics and multiple regression modeling to report on perceptions of entry-level master's level 
counselors and differences that exist between the ratings of entry-level master's level counselors compared to other mental health professionals workıng in college and university counselıng centers

\section{Research Question 1a}

Partıcipants were asked to provide an overall rating of the preparation of various mental health professionals employed at the counselıng center Descriptive statistics were used to compare the overall ratings of master's level counselors to the overall ratıngs of other mental health professionals Specifically, the mean overall scores and standard deviations were reported for each mental health professional

\section{Research Question 1b}

Directors were asked to rate the ability of entry-level master's level counselors to complete varıus tasks and meet specific client needs in a college or university counseling center using a 6-point Likert scale Descriptive statıstics were used to report on the mean ratıng of entry-level master's level counselors for each item Standard deviations were also reported

\section{Research Question 2}

Multiple regression analyses were conducted to predict the score on identıfied factors (e g high risk counseling, low risk counseling, and indirect duties) from the credentials of the director, the director's years of experience in the mental health professional, the director's years of experience as director, the size of the college or university, the number of full time mental health professionals employed by the counseling center, the proportion of master's level counselors to other mental health professionals, and whether the institution is private or public The models generated were 
used to examıne the relationship between predictor varıables and the scores on identıfied factors obtained from evaluatıng the preparation of entry-level master's level counselors to perform tasks and meet client needs associated with work in college and university counseling centers The analyses reported on the percentage of variability in the ratings based on these predictors, and on which percentages were statıstıcally significant

\section{Limitations}

Internal validity is the degree to which observed differences of dependent varıables can be attributed to the independent variables and not to some other variable External validity is concerned with generalizability of the findings to other people, settıngs, treatment variables, and measurement varıables (Campbell \& Stanley, 1963)

Internal threats to this study included history, selection, instrumentation, and attıtude of partıcipants Related to history, partıcıpants' experıences may have influenced responses beyond variables that were measured by the study For example, recent experiences with counselors likely had a greater influence on directors' opinions of counselors preventıng a more accurate overall view of counselors While the entıre population of directors meetıng the established criteria was invited to partıcipate, a selection bias existed due to completion of the survey being voluntary Thus, characteristics may have existed that were different between those that chose to complete the survey instrument and those that did not An instrumentation valıdity threat existed due to researcher bias The instrument was created specifically for this exploratory study, thus this may have influenced items that were included Items could have been included that did not accurately represent tasks of counselors or client needs Additionally, important items could have been excluded despite a review of literature and consultation 
with experts The attitude of participants also created a threat to internal validity Depending on partıcipants' view of the study, responses may have been skewed to more favorably or unfavorably rate entry-level master's level counselors

All internal validity threats also represent potential threats to the generalizability of the results (Campbell \& Stanley, 1963) An additional external valıdity threat was that ecological characteristics may have influenced the return rate among partıcıpants For example, it may have been that partıcıpants from smaller institutions were more or less likely to complete surveys than partıcipants solicited from larger institutions Thus, the finding of the study may be less generalizable in circumstances where data may be limited systematically from some college and university counselıng centers

\section{Strengths of Study}

One strength of the study was the diversity of the population The population was obtained from a comprehensive list of institutions in the U S that included institutions that were accredited and non-accredited, a variety of sizes, and both public and private Additionally, the validity of the survey was increased through the use of an expert panel to review the initial instrument Lastly, basing the survey instrument heavily off of exıstıng studies of college and university counselıng centers, as opposed to existıng trainıng standards, increased the valıdity of the items to actual knowledge and skills needed by practitioners in college and university counseling centers

\section{Summary of Methodology}

This chapter has explained the methods used in this quantitatıve study of college counselıng center director's perceptions of entry-level master's level counselors The next chapter presents the results obtained with those methods 


\section{CHAPTER FOUR}

\section{RESULTS}

The purpose of this research study was to evaluate the adequacy of preparation of master's level counselors for work in college and university counseling centers by examıning the perceptions of counselıng center directors of the ability of entry-level master's level counselors This chapter provides the results of this study This chapter is organized in the following order prelımınary data screenıng and provision of varıables, descriptive data for participants and institutions represented, evaluation of instrument, and analysis of results as they relate to the research questions

\section{Prelımınary Data Screenıng and Provision of Variables}

Prior to analysıs related to research questions, univariate data screenıng was performed for all varıables to look for missing or invalid data utılizing SPSS Frequencies, Explore, and Plot procedures For individual varıables, no varıable had more than $5 \%$ of the cases missing Therefore, listwise deletion was deemed sufficient for reportıng descriptıve statıstics for individual variables

Two additional variables were computed from exısting varıables in preparatıon of data analysis Total number of professionals was computed as a total of clinical professionals that worked within a counseling center from numbers reported for each type of professional LPC proportion was calculated as a ratio of the combined number of master's level and doctoral level counselors to the total number of professionals A Box Plot of total number of professionals revealed four statistical outliers, but these were reviewed and found to be reasonable values and left in the data 


\section{Descriptive Data for Partıcıpants and Institutıons Represented}

Survey instruments were distributed to 1,156 directors of college and university counseling centers in the U S Forty-two Emalls were returned undeliverable reducing the list of partıcipants to 1,114 Of these, 157 partıcipants completed the instrument, representıng a completion rate of $141 \%$

Participants were asked to indicate the experience they have had working with master's level counselors Only $38 \%$ indicated having no experience working with master's level counselors, with most partıcipants indicating that they had been responsible for hirıng decisıons, served as an admınıstratıve or clinical supervisor, or worked as a colleague of a master's level counselor Frequency data for participants' responses are presented in Table 1

Table 1

Experience Working with Master's Level Counselors

$\begin{array}{lll}\text { Experience } & \text { Frequency } & \text { Percentage }^{1}\end{array}$

Responsible for Hurıng 112

$713 \%$

Administratıve Supervisor

115

$732 \%$

Clinical Supervisor

112

$713 \%$

Colleague

120

$764 \%$

No Experience

6

$38 \%$

$N=157$

${ }^{1}$ Participants could select more than one answer, therefore percentages do not total to $100 \%$ 
Partıcıpants were asked to indıcate their gender Descriptıve data for partıcıpants' responses are presented in Table 2

Table 2

Gender of Partıcipants

\begin{tabular}{lcc}
\hline Gender & Frequency & Percent \\
\hline Male & 61 & $389 \%$ \\
Female & 93 & $592 \%$ \\
No Response/Missing & 3 & $19 \%$ \\
Total & $N=157$ & $100 \%$ \\
\hline
\end{tabular}

Particıpants were asked to indicate licenses they currently held Descriptive data for partıcıpants' responses are presented in Table 3

Table 3

License Held by Partıcıpant

License

Frequency $\quad$ Percent $^{\top}$

Psychiatrıst

0

$0 \%$

Social Worker

24

$153 \%$

Counseling Psychologist 
Clinical Psychologist

Professional Counselor

Marriage and Family

Therapist

Registered Nurse/

Nurse Practitioner

No License
2
$223 \%$

$312 \%$

$76 \%$ 7

$45 \%$

2

$N=157$

'Partıcipants could select multıple licenses, therefore percentages do not total to $100 \%$

Participants were asked to indicate years of experience they had in the mental health field and years of experience as directors of college or university counseling centers Descriptıve data for experience are provided in Table 4

Table 4

Years of Experience

Min Max $\quad$ Mean $\quad S D \quad n$

Experience in Mental

Health Field

0

45

1974

999

152

Experience as

Director of College or

0

37

912

799

154

University Counselıng

Center 
Participants were asked to specify the state in which the institution where they worked was located Responses were obtained from directors at institutions in 41 states Descriptıve data for partıcipants' responses are presented in Table 5

Table 5

State Where Institution Located

State

Frequency

Percentage

$\begin{array}{lll}\text { Alabama } & 3 & 19 \% \\ \text { Alaska } & 1 & 06 \% \\ \text { Arızona } & 2 & 13 \% \\ \text { Calıfornıa } & 7 & 45 \% \\ \text { Colorado } & 2 & 13 \% \\ \text { Connectıcut } & 1 & 06 \% \\ \text { Florida } & 5 & 32 \% \\ \text { Georgıa } & 4 & 25 \% \\ \text { Idaho } & 1 & 06 \% \\ \text { Illınoıs } & 7 & 45 \% \\ \text { Indiana } & 5 & 32 \% \\ \text { Iowa } & 4 & 25 \% \\ \text { Kansas } & 1 & 06 \% \\ \text { Kentucky } & 3 & 19 \% \\ \text { Louısiana } & 1 & 06 \% \\ \text { Maine } & 1 & 06 \% \\ \text { Maryland } & 3 & 19 \% \\ \text { Massachusetts } & 6 & 38 \% \\ \text { Mıchigan } & 5 & 32 \% \\ \text { Mınnesota } & 5 & 32 \%\end{array}$




\begin{tabular}{|c|c|c|}
\hline Mississippl & 2 & $13 \%$ \\
\hline Missour1 & 7 & $45 \%$ \\
\hline Nebraska & 1 & $06 \%$ \\
\hline Nevada & 1 & $06 \%$ \\
\hline New Hampshıre & 1 & $06 \%$ \\
\hline New Jersey & 2 & $13 \%$ \\
\hline New York & 11 & $70 \%$ \\
\hline Ohio & 9 & $57 \%$ \\
\hline Oklahoma & 2 & $13 \%$ \\
\hline Oregon & 3 & $19 \%$ \\
\hline Pennsylvanıa & 9 & $57 \%$ \\
\hline Rhode Island & 1 & $06 \%$ \\
\hline South Carolina & 5 & $32 \%$ \\
\hline South Dakota & 1 & $06 \%$ \\
\hline Tennessee & 6 & $38 \%$ \\
\hline Texas & 6 & $38 \%$ \\
\hline Virgınıa & 6 & $38 \%$ \\
\hline Washıngton & 1 & $06 \%$ \\
\hline West Virgınıa & 2 & $13 \%$ \\
\hline Wisconsin & 7 & $45 \%$ \\
\hline Missing & 6 & $38 \%$ \\
\hline Total & $N=157$ & $100 \%$ \\
\hline
\end{tabular}

Participants were asked to indicate the number of students enrolled in the institution where they worked Descriptıve data for the partıcıpants' responses are presented in Table 6 
Table 6

Number of Enrolled Students

Number of Students

Frequency

Percent

Less than 2,500

53

$338 \%$

Between 2,500 and 10,000

63

$401 \%$

Between 10,001 and 20,000

24

$153 \%$

Greater than 20,000

13

$83 \%$

Missing

4

$25 \%$

Total

$N=157$

$100 \%$

Partıcipants were asked to indicate whether the type of institution private (forprofit), private (not-for-profit), or public Descriptıve data are presented in Table 7 Additionally, participants were asked to specify whether their institution was religiously affiliated Of 149 partıcipants responding to this question $396 \%(n=59)$ indicated their instıtutıon was relıgiously affiliated

Table 7

Type of Institutıon

Type of Institution

Frequency

Percent

Private (for-profit)

16

$102 \%$ 
Private (not-for-profit)

Public

Missing

Total
$471 \%$

$395 \%$

$32 \%$

$N=157$

$100 \%$

Participants were asked to indicate the number and type of full time clinicians employed by the counselıng center Descriptive data for clinicians employed are presented in Table 8 Counselıng centers had the highest mean number of master's level counselors $(M=148, S D=190, N=157)$, followed by clinical psychologists $(M=$ $115, S D=261, N=157)$ and counselıng psychologists $(M=100, S D=226, N=157)$ Some clinicians indicated in comments provided that they employed part-time clinicians that could not be indicated in the instrument, and therefore went unrepresented

Table 8

\section{Clinicıans Employed}

\begin{tabular}{lcccc}
\hline Professionals Employed & Mın & Max & Mean & $S D$ \\
\hline Psychiatrists & 0 & 8 & 33 & 103 \\
Clinıcal Psychologists & 0 & 20 & 115 & 261 \\
Counselıng Psychologists & 0 & 20 & 100 & 226 \\
Master's Level Counselors & 0 & 11 & 148 & 190 \\
Doctoral Level Counselors & 0 & 5 & 32 & 77 \\
Master's Level Social Workers & 0 & 6 & 66 & 111
\end{tabular}


Doctoral Level Social Workers

Master's Level

Marriage and Famıly Therapısts

Doctoral Level

\section{Evaluation of Instrument}

An 1tem analysıs and an exploratory factor analysis usıng principal component extraction and an oblique rotation were conducted to determine core factors present in the instrument and to verify that the items in the instrument were appropriate for the purposes of this study The item analysis was conducted on the 31 items from section II and section III of the instrument utılızing the data from the full study All items had correlations greater than 40, and the coefficient alpha for the 31 items was 96

For the factor analysis, an initial concern was the poor to fair sample size for conductıng a factor analysis An ideal number for the number of variables would have been a ratio of 10 participants for each 1tem, or 310 cases (Meyers, Gamst, \& Guarıno, 2006) Despite the small number of partıcıpants, the Ka1ser-Meyer-Olkın (KMO) measure of sampling adequacy was 92 , indicatıng the sample was adequate for factor analysis Barlett's test of sphericity was significant $(p<001)$ and thus rejected the null hypothesis of lack of sufficient correlation between the variables A scree plot suggested 3 factors would be used in the solution representıng $6164 \%$ of the variance

A review of the initial solution revealed that all communalities were greater than 5 except for Supervision, which had a value of 36 Because this item was exceptionally 
low, it was removed from the model and the factor analysis was rerun The final model had 30 1tems and a KMO value of 93 The rotated solution (see Table 9) indicated three factors high risk counselıng, low risk counselıng, and indirect dutıes These factors represented $6368 \%$ of the variance Communalities for the 30 items ranged between 49 and 79

Table 9

Correlatıons between Items and Identified Factors

Factors

Item

High Risk Low Risk

Indirect Duties

High Risk Counselıng Items

Schizophrenia and Other Psychotic

Features

.85

07

15

Risk of Harm to Others

.82

28

00

Trauma Related Issues

.79

20

23

Personality Disorders

.79

16

29

Self-ınjury Behaviors

.78

29

20

Substance Abuse and

Addictıve/Compulsıve Behaviors

.76

15

17

Eatıng Related Issues

.75

22

22

Psychotropıc Medıcatıons

.74

21

18

Suicidal Ideation or Attempts

.72

36

10 
Crisis Intervention

Couples and Family Counselıng

Assessment and Diagnosis

Consultation

Low Risk Counselıng Items

Self-Concept Issues

Career Related Issues

Relatıonal Difficulties

Special Student Populations

Learnıng/Academıc Concerns

Anger Issues

Mood Related Issues

Individual Counselıng

Stress, Anxiety, and Phobıas

Referrals

Indirect Duties Items

Conductıng Research and Evaluation

Utılızıng Research

Administration

Management of Ethical and Legal

Issues/R1sks

Complexly Determined Items
5
36

34

19

28

.82

.70

.65

.64

.63

.62

.54

26 .77

21

.69

37

.56 
Sexual Identity Issues

Group Counselıng

Outreach
53

51

06
46

42

55
16

36

54

Factor 1, with 13 1tems, represented high risk counselıng (eigenvalue $=884$ ) and accounted for $2852 \%$ of the variance Items within this factor related to counseling high rısk clients or in high risk situatıons, often demandıng specialızed skılls Factor 2, with 10 items represented low risk counselng (eigenvalue $=666$ ) and accounted for $2147 \%$ of the variance These items related to counselıng low risk clients that typically demand less specialized skılls Factor 3, with 4 tems, represented indırect duties (eigenvalue $=361$ ) and accounted for $1165 \%$ of the variance These 4 items related to functions such as admınıstratıve duties and research Three items, sexual identity issues, group counselıng, and outreach, loaded on multıple factors

Based on these findings three new variables were created representıng the total of items in each factor high risk counseling, low risk counseling, and indirect duties Complexly determined items were added to the factor that they loaded the highest on In initial totals, missing values among individual 1tems caused up to 11 missing cases on the factor scores Because this represented greater than $5 \%$ of the cases, mean substitution was used to replace missing data on individual items, and the totals were recomputed for the new varıables Results from the item analysıs and factor analysıs support the appropriateness of items included in the instrument for purpose of this study 


\section{Research Question 1}

The first research question sought to answer How do college and university counselıng center directors rate the adequacy of preparation of entry-level master's level counselors for work as mental health professionals within their centers? The first of two sub-questions to explore this question was How do the director's overall ratıngs of entrylevel master's level counselors compare to overall ratıngs for other credentraled mental health professionals in similar positions? This question was explored through descriptive statıstıcs of the overall ratıngs

Participants provided an overall ratıng of various clinical professions that may work in a college or university counselıng center Specifically, partıcıpants were to rate whether they Strongly Disagree, Moderately Disagree, Somewhat Disagree, Somewhat Agree, Moderately Agree, or Strongly Agree that each category of professional was overall prepared to meet client needs and perform specific tasks associated with work in a college or university counselıng center Results indicated that $752 \%$ somewhat or moderately agreed that entry-level master's level counselors were overall prepared to meet client needs and conduct associated tasks of clınicians in a college or university counselıng center Frequency data for overall ratıngs are presented in Table 10

Table 10

Frequenctes of Overall Rating of Master's Level Counselors

Frequency

Strongly Disagree
Percent

$06 \%$ 
Moderately Disagree

Somewhat Disagree

Somewhat Agree

Moderately Agree

Strongly Agree

Total
5

6

46

72

27
$32 \%$

$38 \%$

$293 \%$

$459 \%$

$172 \%$

$N=157$

$100 \%$

For purposes of comparıng ratıngs, a numeric value was assigned to each of the Likert-scale values, beginnıng with a 1 for Strongly Disagree to a 6 for Strongly Agree Means and standard deviations were then calculated for the overall rating of each type of professional (see Table 11) Using this method, Clınıcal Psychologists were rated highest $(M=523, S D=78, N=157)$, and master's level counselors were rated 6 th $(M=468$, $S D=95, N=157$ ) Of note, master's level counselors were rated the highest of master's level professionals

Table 11

Descriptive Statıstics for Overall Ratıng of Mental Health Professionals

\begin{tabular}{lccccc}
\hline Credential & Min & Max & Mean & SD & $n$ \\
\hline Counseling Psychologist & 3 & 6 & 536 & 69 & 155 \\
Clinical Psychologist & 2 & 6 & 523 & 78 & 157 \\
Doctoral Level Counselor & 2 & 6 & 512 & 78 & 155
\end{tabular}




\begin{tabular}{|c|c|c|c|c|c|}
\hline Doctoral Level Social Worker & 2 & 6 & 492 & 89 & 154 \\
\hline Psychiatrist & 1 & 6 & 483 & 102 & 156 \\
\hline Master's Level Counselor & 1 & 6 & 468 & 95 & 157 \\
\hline Master's Level Social Worker & 1 & 6 & 459 & 100 & 157 \\
\hline $\begin{array}{l}\text { Doctoral Level Marriage and Family } \\
\text { Therapist }\end{array}$ & 1 & 6 & 455 & 115 & 155 \\
\hline $\begin{array}{l}\text { Master's Level Marriage and Famıly } \\
\text { Therapist }\end{array}$ & 1 & 6 & 424 & 111 & 155 \\
\hline $\begin{array}{l}\text { Master's Level Rehabilitation } \\
\text { Counselor }\end{array}$ & 1 & 6 & 375 & 122 & 155 \\
\hline
\end{tabular}

The second sub-question for research question one asked How do directors rate the ability of entry-level master's level counselors to meet the needs of clients and perform specific tasks associated with mental health professionals in a college or university counselıng center? This question was answered utılizing data collected from sections II and III of the instrument

In section II of the instrument, participants rated their perception of the ability of entry-level master's level counselors to meet client needs in a college or university counselıng center For purposes of reportıng ratıngs, a numeric value was assigned to each of the Likert-scale values, beginning with a 1 for Strongly Disagree to a 6 for Strongly Agree Means and standard deviatıons were then calculated for each ratıng (see Table 12) Counselors were rated highest in their ability to meet client needs related to Relational Difficulties $(M=516, S D=82, N=157)$, Self-Concept Issues $(M=509, S D$ $=82, N=157)$, and Mood Related Issues $(M=499, S D=89, n=156)$ Counselors 
were rated lowest in their ability to meet client needs related to Schızophrenıa and Other

Psychotıc Features $(M=354, S D=131, N=157)$, Psychotropıc Medıcatıons $(M=359$, $S D=127, n=156)$, and Personality Disorders $(M=371, S D=137, N=157)$

Table 12

Ratings of Entry-Level Master's Level Counselors Abllity to Meet Client Needs

Client Need

Relational Difficulties

Self-Concept Issues

Mood Related Issues

Learnıng/Academic Concerns

Stress, Anxiety, and Phobias

Career Related Issues

Anger Issues

Special Student Populations

Suicidal Ideation or Attempts

Sexual Identity Issues

Substance Abuse and

Addictive/Compulsive Behaviors

Self-Injury Behaviors

Risk of Harm to Others

Trauma Related Issues
Mean

516

82

157

509

82

157

499

89

156

490

94

156

490

90

156

477

104

157

469

95

156

469

97

157

441

115

157

438

111

157

420

111

157

417

113

157

404

127

155

404

137

156 
Eatıng Related Issues

Personality Disorders

Psychotropic Medications

Schizophrenia and Other Psychotic

Features

For Section III, partıcıpants rated the perceived ability of master's level entrylevel counselors to perform specific roles (see Table 13) Counselors were rated highest in their abılity to perform Indıvidual Counselıng $(M=525, S D=88, n=156)$, Outreach $(M=496, S D=102, n=156)$, and Admınıstration $(M=495, S D=115, n=156)$ Counselors were rated lowest in their ability to perform Supervision $(M=288, S D=$ $142, n=155)$, Consultation $(M=406, S D=122, N=157)$, and Assessment and Diagnosis $(M=414, S D=119, n=156)$

Table 13

Ratıng of Entry-level Master's Level Counselors Abllty to Perform Roles

\begin{tabular}{lccc}
\hline Role & Mean & $S D$ & $n$ \\
\hline Individual Counseling & 525 & 88 & 156 \\
Outreach & 496 & 102 & 156 \\
Administration & 495 & 115 & 156 \\
Referrals & 474 & 107 & 157 \\
Management of Ethical and & 472 & 111 & 157
\end{tabular}


Legal

Issues/R1sks

Group Counselıng

466

116

156

Utılızıng Research

461

113

157

Crisis Intervention

431

119

155

Couples and Famıly Counselıng

Conducting Research and

421

130

157

Evaluation

Assessment and Diagnosis

414

119

156

Consultation

406

122

157

Supervision

288

142

155

\section{Open Response Data}

Additional information about participants' views regarding the preparation of master's level counselors was collected through an optional free response section of the survey instrument (section VI of the survey instrument) Sixty-eight partıcıpants provided comments in this section These comments were reviewed and are presented based on common themes

Entry-Level Counselors as Adequately Prepared. Comments by some of the partıcipants indicated that they felt that counselors were adequately prepared for work in college or university counselıng centers Examples included a statement indicatıng they were "overall impressed with the preparation and readiness of master's level counselors" 
and a statement that master's level counselors were "very adequately equipped to work fully with clients"

Some participants indicated feelıng that master's level counselors were better prepared than others due to doctoral level psychologists being "often too focused on diagnosing disorders and not attentive enough to the whole person and the person-inenvironment adaptation," and statıng that psychologists are "often not trained in advocacy for clients, which is very valuable and appropriate to the college counseling center environment " Furthermore, master's level counselors were perceived by one participant as "much more in tune with the strengths-based approach that can be quite successful in a college settıng "

Others noted feelıng that master's level counselors may lack some skills of other clinicians, but that the skılls they lacked were not essential "We'd prefer to see more seasonıng for professionals when we're coping with life-threatenıng concerns (cuttıng, disorders, suicidal ideation) but, candidly, we can always refer our students to offcampus veterans for those worries "

Entry-Level Counselor Preparation as Depending on Multiple Factors. The bulk of participants providing optional comments stated that the adequacy of preparation was inconsistent For example, one participant stated

It has been my observation that the quality of master level trainıng programs are highly variable I have worked with new master level therapısts who have never done an intake, who have case conceptualization issues, and who have little or no knowledge of common psychotropıc medications In additıon, their writıng skılls are appallıng and they have little experience with critical thinkıng On the other 
hand, I have worked with experienced master level mental health professionals who are highly knowledgeable and skıll and gifted clınicians

Some participants attributed these differences to a variance in training-related or individual factors of the counselor Training-related factors noted included the quality of the training program attended and quality and relevancy of field experiences Individual factors noted included age, life expenences, maturity, and personality "I believe that many master's level counselor can be very effectıve Much depends on age, maturity, and experience My master's level [counselor] is more experienced, and in many ways, more effective as a counselor than some of the doctoral level counselors that I have had in the past "

Entry-Level Counselors as Inadequately Prepared. Some participants stated that they felt master's level counselors were inadequately prepared, with areas of deficiency noted as ethics, substance abuse, crisıs management, diagnosis, application of theory, developmental knowledge, and risk assessment However, many comments suggested that master's level counselors could become adequate through additional supervision and experience "In my experience, entry-level counselors are prepared with basıc academıc knowledge and convert this knowledge to skılls readıly as experience is gained under supervision " Others felt that the additional supervision and experience needed were beyond what they were willing or had the time to provide "I believe that master's level counselors have the capability to learn and quickly adapt we just don't have the tıme or the personnel avallable to provide this trainıng " Stıll another noted the viewpoint that in settıngs such as rural locations of big institutions, master's level clinıcians lacked the advanced skılls needed 
A two year graduate program is not sufficient to work in our setting which requires the knowledge, experience, and ability to work with clinical complexity (personality disorders, severe axıs I disorders), provide diagnosıs (many masters programs I find do not require a graduate level course in psychopathology), provide multicultural competent counseling (I find that many masters programs do not require a course in multıcultural counseling), conduct testıng and assessment (which is not permitted without a doctoral level in our state), or provide clinical supervision for doctoral trainees (no coursework in clinical supervision, cannot oversee testıng/research ) Most masters programs also do not require a thesis so I am not confident in counselors' ability to provide empirically supported treatments If ours were a small agency that only provided short-term counselıng (no clinical training or supervision, referring out for more severe clinical cases, no testing or assessment), then someone with a terminal masters degree might be well-suited

One last concern raised regarding master's level counselors related the problem of perceived ability Multiple participants noted that it is important that clinicians have doctoral degrees so that they have credibility with students and faculty, many of whom have $\mathrm{PhD}$ degrees or are workıng on advanced degrees Of additıonal concern was the age of master's level counselors One partıcipant presumed that master's level clinıcians would be younger, which would result in the professional having less crediblity with older students and faculty 


\section{Research Question 2}

The second research question asked To what extent do the credentials of the counseling center director, the number of years he or she has been a mental health professional, the number of years he or she has been a director, the size of the college or university, the number of full time mental health professionals in the counseling center, the proportion of counselors to other mental health professionals on staff, and whether the institution is public or private predict perceptions of the preparation of entry-level master's level counselors for work in a college or university counseling center? To answer this question multiple regression analyses were conducted utılızing the three factors (e g high risk counseling, low risk counseling, and indirect duties) identıfied in the exploratory factor analysis as dependent variables

Prior to conductıng multıple regression analyses, data screening was conducted to check for outliers and to assess for normality and homoscadasticity A Box Plot revealed two cases as statistical outhers for high risk counseling Reviewing these cases showed that responses represented disproportionately low ratings on related items Because these cases represented less than $5 \%$ of the data, they were removed Using Mahalanobis distance, no multivariate outliers were found in the cases $(p>001)$

Regarding normality, years of experience as director and total number of professionals were both found to be positively skewed beyond an acceptable range $(>10)$ Both were transformed using a log base 10 transformation to induce normality The histogram for $L P C$ proportion indicated a trimodal distribution Due to the violation of the normality assumption, it was decided to instead replace this variable with at least one professional counselor, a dichotomous variable computed that indicated if the 
counselıng center employed at least one full tıme professional counselor No other concerns were found related to normality for indıvidual varıables

Scatterplots were generated to verify linearity and homoscadasticity between each factor and years experience in mental health, $\log 10$ years experience as director, and log 10 total professionals Scatterplots revealed linear relatıonships among all varıables Additionally, a scatterplot revealed a possible variation from homoscadasticity in the relationship of low risk counseling and log 10 years as director and between low risk counseling and $\log 10$ total professionals

A multiple regression analysis was conducted to predict indirect duties from the credentials of the counseling center director, the number of years he or she had been a mental health professional, the number of years he or she had been a director, the size of the college or university, the number of full time mental health professionals in the counseling center, whether or not the counseling center employed at least one professional counselor, and whether the institution was public The results of this analysis indicate that the linear combination of predictors did not account for a statıstically significant amount of indirect duties varıability, $R^{2}=15, F(13,130)=173, p=06$ All Tolerance statıstic values were withın an appropriate range $(>1)$, suggestıng that multicollinearity was not an issue A summary of regression coefficients is presented in Table 14 Only the variable counseling psychologist significantly contributed to the model 
Table 14

Coefficients for Indirect Duties Model $(n=144)$

\begin{tabular}{|c|c|c|c|c|c|c|}
\hline Variable & $B$ & $S E(B)$ & $\beta$ & $t$ & $\operatorname{Sig}(p)$ & Partial \\
\hline At least one counselor & 111 & 76 & 14 & 147 & 14 & 13 \\
\hline Log 10 Total Professionals & -12 & 130 & -01 & -09 & 93 & -01 \\
\hline Log 10 Years as Director & 133 & 86 & 15 & 154 & 13 & 13 \\
\hline Public & -45 & 73 & -06 & -61 & 54 & -05 \\
\hline $\begin{array}{l}\text { Student Size 2,500 to } \\
10,000\end{array}$ & 62 & 77 & 08 & 81 & 42 & 07 \\
\hline $\begin{array}{l}\text { Student Size } 10,001 \text { to } \\
20,000\end{array}$ & 116 & 120 & 12 & 97 & 34 & 09 \\
\hline Student Size Over 20,000 & -13 & 170 & -01 & -08 & 94 & -01 \\
\hline Years Experience & -03 & 04 & -08 & -75 & 46 & -07 \\
\hline Social Worker & 43 & 110 & 04 & 39 & 70 & 30 \\
\hline Counselıng Psychologist & -246 & 98 & -29 & -251 & 01 & -22 \\
\hline Clınıcal Psychologist & -148 & 92 & -18 & -160 & 11 & -14 \\
\hline Professional Counselor & -93 & 95 & -12 & -98 & 33 & -09 \\
\hline $\begin{array}{l}\text { Marriage and Family } \\
\text { Therapist }\end{array}$ & 164 & 118 & 13 & 139 & 17 & 12 \\
\hline
\end{tabular}

A second multıple regression analysıs was conducted to predict high risk counseling from the credentials of the counseling center director, the number of years he or she had been a mental health professional, the number of years he or she had been a 
director, the size of the college or university, the number of full time mental health professionals in the counseling center, whether or not the counseling center employed at least one professional counselor, and whether the institution was public The results of this analysis indicate that the overall model did not significantly predict high risk counselıng, $R^{2}=13, F(13,128)=149, p=13$ All Tolerance statıstıc values were withın an appropriate range ( $>1)$, suggestıng that multicollinearity was not an issue $\mathrm{A}$ summary of regression coefficients is presented in Table 15 The variables counseling psychologist and log 10 years as director significantly contributed to the model

Table 15

Coefficients for High Risk Counseling Model $(n=142)$

\begin{tabular}{lrrrrrr}
\hline Variable & $B$ & $S E(B)$ & $\beta$ & $t$ & Sig $(p)$ & Partıal \\
\hline At least one counselor & 94 & 275 & 03 & 34 & 73 & 03 \\
Log 10 Total Professionals & 13 & 462 & -00 & 03 & 98 & 00 \\
Log 10 Years as Director & 680 & 310 & 22 & 219 & 03 & 19 \\
Public & 60 & 264 & 02 & 23 & 82 & 02 \\
Student Size 2,500 to & 360 & 276 & 14 & 130 & 20 & 11 \\
10,000 & & & & & & \\
Student Size 10,001 to & 766 & 429 & 22 & 179 & 08 & 16 \\
20,000 & & & & & & \\
Student Size Over 20,000 & 492 & 636 & 10 & 77 & 44 & 07 \\
Years Experience & -18 & 13 & -14 & -133 & 19 & -11 \\
Social Worker & 326 & 392 & 09 & 83 & 41 & 07
\end{tabular}




\begin{tabular}{|c|c|c|c|c|c|c|}
\hline Counselıng Psychologist & -816 & 354 & -27 & -231 & 02 & -19 \\
\hline Clınıcal Psychologist & -269 & 332 & -09 & -81 & 42 & -07 \\
\hline Professional Counselor & -520 & 340 & -19 & -153 & 13 & -13 \\
\hline $\begin{array}{l}\text { Marriage and Family } \\
\text { Therapist }\end{array}$ & 150 & 422 & 03 & 36 & 72 & 03 \\
\hline
\end{tabular}

A third multıple regression analysis was conducted to predict low risk counseling from the credentials of the counseling center director, the number of years he or she had been a mental health professional, the number of years he or she had been a director, the size of the college or university, the number of full time mental health professionals in the counselıng center, whether or not the counseling center employed at least one professional counselor, and whether the institution was public (see Table 16) The results of this analysis indicate that the overall model did not significantly predict low risk counseling, $R^{2}=07, F(13,130)=78, p=66$, and none of the individual variables significantly contributed to the model All Tolerance statistic values were within an appropriate range ( $>1)$, suggestıng that multicollinearity was not an issue

Table 16

Coefficients for Low Risk Counseling Model ( $n=144)$

\begin{tabular}{lcccccc}
\hline Varıable & $B$ & $S E(B)$ & $\beta$ & $t$ & Sig $(p)$ & Partial \\
\hline At least one counselor & 194 & 152 & 12 & 128 & 20 & 11 \\
Log 10 Total Professionals & 87 & 258 & 05 & 34 & 74 & 03
\end{tabular}




$\begin{array}{lrrrrrr}\text { Log } 10 \text { Years as Director } & 50 & 174 & 03 & 29 & 77 & 03 \\ \text { Public } & 65 & 146 & 05 & 45 & 66 & 04 \\ \begin{array}{l}\text { Student Size 2,500 to } \\ 10,000\end{array} & -37 & 155 & -03 & -24 & 81 & -02 \\ \begin{array}{l}\text { Student Size 10,001 to } \\ 20,000\end{array} & 188 & 241 & 10 & 78 & 44 & 07 \\ \text { Student Size Over 20,000 } & -217 & 348 & -08 & -62 & 53 & -06 \\ \text { Years Expenience } & -001 & 08 & -02 & -18 & 86 & -02 \\ \text { Social Worker } & 42 & 220 & 02 & 19 & 85 & 02 \\ \text { Counseling Psychologist } & -287 & 196 & -17 & -146 & 15 & -13 \\ \text { Clinical Psychologist } & -218 & 186 & -14 & -117 & 24 & -10 \\ \text { Professional Counselor } & -205 & 190 & -14 & -108 & 28 & -09 \\ \text { Marriage and Family } & 185 & 237 & 07 & 78 & 44 & 07 \\ \text { Therapist } & & & & & & \end{array}$

Note Type of degree was represented with five dummy variables with Other represented as the reference group 


\section{CHAPTER FIVE}

\section{DISCUSSION}

This chapter presents a discussion of the results of this study This chapter is organized in the following order summary of findıngs, implicatıons for college and university counselıng center clinical supervisors, implicatıons for college and university counselıng center directors, implications for counselor educators, implications for master's level counselors and counselor trainees seeking employment in college and university counselıng centers, implications for counselor educators, limitations of the study, and suggestions for future research

\section{Summary of Findings}

The purpose of this study was to investigate the adequacy of preparation of entrylevel master's level counselors for professional positions in college and university counseling centers Preparation was assessed by surveyıng college and university counseling center directors' perceptions regarding the ability of entry-level master's level counselors to meet client needs and perform relevant roles The population used for the survey was directors of college and university counselıng centers at institutions in the U S that had at least 1,000 students enrolled and offered on campus housing Of 1,114 directors receiving the study, 157 completed the instrument for a completion rate of $141 \%$

A diversity of participants and institutions were represented in the study Participants represented in the study included professional counselors, clinical and counselor psychologists, social workers, marriage and famıly therapısts, and registered nurses Participants on average had approximately 20 years experıence in mental health 
and 9 years of experience as a college or unıversity counseling center director Over $96 \%$ indicated that they had some experience working with master's level counselors Over $59 \%$ indicated being female

Institutions from 41 states were represented in the study, and included various size institutions ranging from small institutions with less than 2,500 students to large institutions with over 20,000 students enrolled Approximately three quarters of the participants were from schools with 10,000 or less students enrolled The majority of participants (approxımately 57\%) worked for private institutions, with over 39\% indicatıng the institution was religiously affiliated

Directors reported employing a range of mental health professionals including psychiatrists, clinical psychologists, counselor psychologists, master's and doctoral level professional counselors, master's and doctoral level clinical social workers, master's and doctoral level marriage and family therapists, and rehabilitation counselors Counseling centers had the highest mean number of master's level counselors employed, followed by clinical and counseling psychologists The distribution of demographics and institutional characteristics were similar to statıstıcs reported by the annual survey of college counselıng center directors by the ACCA (Gallagher, 2009) suggestıng that the sample was representatıve of the broader population of directors in U S colleges and university counseling centers

\section{Research Question 1}

The results of this study found that over $92 \%$ agreed to some extent that entrylevel master's level counselors were overall capable of meetıng client needs and performing associated roles associated with work of mental health professionals in a 
college or university counseling center Additionally, master's level counselors were rated the highest overall of master's level clinicians On indıvidual ratıngs, counselors were rated highest in providıng indıvidual counselıng and providıng services related to relatıonal difficulties and self-concept issues Counselors were rated lowest in providing supervision, in understanding issues related to psychotropic medications, and in workıng with clients with schizophrenia and other psychotic features Only with regard to supervision were entry-level master's level counselors rated on average as not being capable This ratıng was not surprising considerıng supervision is not a core part of master's level counselor trainıng standards and in some states supervision requires additional coursework and experience beyond a master's degree (Bernard \& Goodyear, 2009, CACREP, 2009)

Nonetheless, entry-level master's level counselors were rated overall below entrylevel counselıng psychologists, clinical psychologist, doctoral level counselors, doctoral level social workers, and psychıatrısts Negatıve ratıngs and open-ended responses of some participants further illuminated that these differences were perceived as a concern by some and had an impact on hiring decisions Some responses suggested that dıfferences in ratıngs could have been partly accounted for by the additional experience that doctoral level clinicians have as part of their degree requirement (e g , additional hours required as part of internship and practicum experience in psychology degrees) Other responses noted that there was significant variance in the ability of entry-level counselors that was dependent on factors including the program they graduated from, the quality and relevance of the counselor internship experience, and individual traits includıng age and life experiences 
As addressed in Chapter 2, there is a lack of research examınıng the preparation of mental health professionals for work in college and university counselıng centers (Bishop, 2006) The results of this study had simılaritıes and differences from Martın, Partın, and Trivette's (1998) study of counselors workıng in mental health agencies with regard to ratıngs of mental health professionals Similarly, counselors in their study were rated on average qualified to meet client needs Results also corresponded with high ratings found in their study of counselors in the areas of individual counseling, adminıstratıon, and management of ethıcal and legal ıssues Also, Martın, Partın, and Trivette (1998) simılarly reported directors' perceptions of counselors being less skilled in the areas of supervision, psychotropic medication, and psychopathology

However, in overall ratıngs Martın, Partın, and Trivette (1998) found clınıcal social workers were rated the highest overall, followed by psychıatrısts, psychologists, and then professional counselors In contrast, in this study, psychologists were rated the highest, with social workers rated lower than psychiatrists and counselors Differences in findings may be accounted for in part by different demands and client needs between community mental health centers versus college and university counseling centers Other differences include that Martın, Partın, and Trivette's study was focused on evaluatıng all licensed mental health professionals as opposed to only entry-level mental health professionals and their study was specific to mental health professionals in Ohio Moreover, Martın, Partın, and Trivette hypothesized that the fact that most of the directors were clinical social workers in their study may have biased ratıngs of clinical social workers 


\section{Research Question 2}

Additionally, this study looked for factors that may have influenced ratıngs of entry-level master's level counselors No statıstically significant effect on ratıngs was found as a result of the credentials of the counseling center director, the number of years he or she had been a mental health professional, the number of years he or she had been a director, the size of the college or university, the number of full time mental health professionals employed by the counselıng center, whether or not the counseling center employed at least one counselor, or whether the institution was public or private

These results contrasted with Martın, Partın, and Trivette's (1998) study that found counselors were rated lower by clinical social workers than by other counselors Martın, Partın, and Trivette suggested that the results of their study might represent the preference of directors for clinicians with simılar credentıals Given that psychologists were represented in the greatest number in this study, one might have expected a statıstically significant difference in ratıngs of counselors by psychologists In the results, whether the director was a counseling psychologist contributed significantly to the models for predicting scores on counselors' abılity to perform indırect duties and respond to high risk client needs However, the models themselves were not found to be statistically significant

Additıonally, Destefano, Petersen, Skwerer, and Bickel's (2001) study found differences among the importance directors gave to varıous roles of counselors based on the years of experience of the director, the size of the institution, and whether the ınstitution was public or private Vespia (2007) also found differences between small and large institutions in staffing and in practices of assessment, diagnosis, and treatment 
However, in this study these differences were not significant predictors of combined ratıngs of the abilities of entry-level master's level counselors

Implicatıons for College and Unıversity Counselıng Center Clınıcal Supervisors

Findıngs from this study indicate that entry-level master's level counselors are overall prepared for work in college and university counselıng centers in all areas except for supervision, with marginal concerns related to identıfying, helping, or referring clients related to personality disorders, psychotropıc medicatıons, and schizophrenıa and other psychotic features As noted, supervision is not a typical role of entry-level counselors, many of whom would also be contınung under supervision themselves towards licensure However, because of the increasing importance being given to college and university counselors handlıng more severe mental health concerns (e g , B1shop, 2006, Gallagher, 2009 , Kitzrow, 2003) perceived deficiencies related to other areas would warrant attention from clinical supervisors of master's level counselors working in college and university counseling centers Specifically, clinical supervisors would be recommended to assess counselors' abilities in areas rated less favorably and to provide additional trainıng where necessary

\section{Implications for College and Unıversity Counselıng Center Directors}

Based on the finding that entry-level master's level counselors were on average rated as capable in almost all areas surveyed, directors can feel overall confident employing master's level counselors in their centers At the same time, many directors voiced concerns about inconsistencies in the preparation of master's level counselors and about a perceived lack of resources to provide the supervision and training necessary to address areas perceived of as deficient 
Directors can address the issue of inconsistency by better screening applicants based on the training program the applicant attended, on the applicability of practicum and internship experiences durıng trainıng, and on additional trainıng or experience applicants may have had Related to the training program attended, key areas to assess would be whether the program was CACREP accredited, the number of hours completed as part of the degree, and the areas of coursework completed Additionally, by developing relationshıps with local counselor trainıng programs and by providing internship positions to trainees, directors can obtain more information about the quality of potential applicants from those programs

Related to limited resources for traınıng and supervision, some directors perceived entry-level master's level counselors as needıng extensive additıonal trainıng and supervision in order to be prepared for work in college and university counseling centers Arguably, this viewpoint is based on a model that posits that all mental health professionals workıng in college and unıversity should be highly skılled generalısts In contrast, other directors viewed master's level counselors as bringing unique strengths and mınımızed concerns about master's level counselors' capabilitıes statıng that when counselors encountered issues for which they were not prepared they could refer clients to more qualified mental health professionals at the counseling center or to resources in the community In the later perspective, it would only be essential that master's level counselors could identify and refer cases that exceed their qualıfications Moreover, entry-level positions could also be lower pay, saving the counselıng center money and potentrally allowing for the hirıng of additional mental health professionals 


\section{Implicatıons for Master's Level Counselors and Counselor Tramees Seekıng Employment in College and University Counselıng Centers}

While the finding that entry-level counselors were rated on average as capable in almost all areas surveyed, many directors were more critical of the preparation of counselors Entry-level master's level counselors seeking work in centers with directors of simılar opınıons may face difficulties being hired, if not being excluded entırely from the hiring pool Most directors expressed that they felt master's level counselors would close any perceived gap in preparation with additional experience and supervision In this way, hirıng concerns may relate primarıly to candidates without any prior counselıng experience

For counselor trainees intending to work in college or university counseling centers, one way of mitigating concerns of more critical directors would be through obtaınıng practıcum and internship experiences related to college counselıng Also, counselors unable to find immediate work in college or university counseling positions upon graduatıng may have to seek out "bridge positions" that will gain them additional experience and supervision to advance their clinıcal skılls Additionally, master's level counselors may want to consider further training and experience through a doctoral degree in counselıng or counselor education Many directors noted that the doctoral degree provides additional job opportunities and helps mental health professionals practıcing in higher education settıngs have greater credibility with admınıstrators, students, and faculty Additionally, CACREP (2009) standards include training in supervision as part of the doctoral degree requirement, which was an area where entrylevel counselors were noted as lackıng preparatıon 


\section{Implications for Counselor Educators}

The results of this study support that counselor traınıng programs are adequately preparıng counselors for work in college and university counselıng centers, while also revealıng areas for improvement Specifically, trainıng programs could increase trainıng in areas where counselors were rated lower including identıfyıng, helpıng, or referrıng clients related to personality disorders, psychotropic medications, and schizophrenia and other psychotıc features Additionally, training programs could focus on helping trainees with an interest in college counseling obtain internships that better prepare them for work in that setting

The results of the study also affirm the importance of CACREP (2009) training standards Multiple participants commented that there were large inconsistencies between master's level counselors Others noted that they would only hire counselors from programs that they knew provided quality training Ideally, CACREP standards would become a standard that directors would come to trust as a mark of a high quality counselor trainıng program At the same tıme, CACREP standards for Student Affairs and College Counselıng may be doing a disservice to counselor trannees seekıng work in college and university counselıng centers Unlıke Clınıcal Mental Health Counselıng standards that are migratıng to requirıng 60 semester credits hours, the Student Affairs and College Counselıng track only requires 48 semester credit hours

Additıonally, Student Affarrs and College Counseling standards lack a requirement for being able to conduct multi-axial dragnosis utılizing the Diagnostic and Statistical Manual of Mental Disorders (DSM) and do not require any knowledge of psychotropic medications These omissions, which are part of the Clinical Mental Health 
Counselıng standards, may put graduates of the supposed "college counselıng" track at a disadvantage for some college and university counseling positions Based on the results of this study, students would benefit by being made aware of the how differences in educatıonal tracks may have an impact on their future career optıons withın college and university counseling centers

Finally, counselor educators can play an important role as advocates for counselors among the college and university campuses where they work One director who had an overall unfavorable view of counselor preparation noted that he or she would hire counselors from the counseling graduate program at the institution where he or she worked Presumably, the relatıonshıp hostıng interns and interacting with faculty in the program developed a level of trust in the quality of counselors produced from that

program Developing relationships with the counseling center of one's own institution also creates an avenue to better assess and address any concerns directors may have about counselor preparation Additionally, beyond workıng more closely with counselıng centers, involvement in campus issues related to mental health could also increase the visibility of counselors, and promote their capabilities among campus admınıstrators, faculty, and staff

\section{Limitations of the Study}

Limitations exist in this study that should be considered in the interpretation of results These limitations relate to the instrument and the sample used

\section{Instrumentation limitations}

As an exploratory study the instrument ut1lized in the study was created specifically for this study While steps were taken to review the validity of the 
instrument, its novelty increases the possibility that items were not representatıve of the requirements of counselors in college and university counseling centers Additionally, the instrument did not weight the importance of items Thus, ratings of potentially less important areas may distort conclusions on the overall preparation of counselors Simılarly, some 1ssues may be more or less important based on institutional characterıstıcs, which may limit generalızatıons to some college and unıversity counseling centers

Additionally, this study makes an inference on preparation based on an assessment of capabilities As many participants noted in comments, the capabilities of counselors may be related substantially to individual factors that do not reflect on the quality of the training program the counselors attended This variance due to individual factors may limit the ability to extract from data broader implicatıons about counselor preparation for college and university counseling centers

Feedback from partıcipants also raised some additıonal potential limitations Some participants' comments indicated that there might have been some confusion related to the term "master's level counselor " Despite being defined in the survey instrument, some partıcıpants may have generalızed this term to represent all master's level clinicians including those with degrees in psychology and social work If true, this may have distorted some of the findings to be more indicatıve of master's level clinicians in general, rather than specifically about clınicians with a master's degree in counseling

\section{Samplıng lımitations}

Related to sampling limitations, a relatively low percentage of the population surveyed completed the instrument, which may affect generalızability Specifically, the 
low completion rate increases the risk of self-selection bias, the potential that differences may have existed between the directors that completed the instrument and those that did not On this issue, a few emails were received from directors who indicated that they were not completıng the study because the counseling center they worked for did not employ master's level counselors or did not currently have master's level counselors on staff While these directors were emalled back and notıfied that this was not a prerequisite for completing the study, it is possible that a number of directors may have falled to complete the study based on this perception At the same tıme, since the study did not require a mınımum amount of experience with master's level counselors to complete the instrument, results may be skewed by perceptions that do not accurately reflect on the actual capabilities of counselors Similarly, participants may have responded to the survey instrument based on older experiences, not reflective of current standards of training

The sample for the survey was also limited to directors of 4-year institutions in the U S which offered on-campus housing and had at least 1,000 students enrolled Research has found that counselıng services of 4-year institutions vary significantly from those offered by community colleges (American College Counseling Association, 2010, Gallagher, 2009) Examples of differences include that community college counseling centers often employee a higher percentage of master's level counselors, are less likely to serve a residential community, and are more likely to serve additional roles such as academic advising Thus, results are not likely generalızeable to the community college settıng 
Constraints related to on-campus housıng and mınımum student numbers were primarily created to increase the likelihood that the institution offered mental health counselıng services For example, some of the institutions excluded from the study included a college reporting only nine enrolled students with one instructor and an institution offering only onlıne degrees However, results of the study would likely apply to any sized institution that offers counselıng services similar in scope to the institutions represented in the study

\section{Suggestions for Future Research}

As a follow up to this study, future research could explore other perspectives of master's level counselor preparatıon for work in college and unıversity counselıng centers One suggested approach would be to survey master's level counselors who are currently working in college and university counseling centers about their perceptions of their preparation These data could then be compared and contrasted with the results of this study for a more thorough representation of counselor preparation

Additionally, it is important to further explore the importance of varıous roles and clients needs evaluated in this study Better understanding the relevant importance directors and mental health professionals place on different roles they perform and different client needs they address in college and university counseling centers will help prioritize areas for trainıng programs to improve While there are a number of studies that have researched the prioritization of roles and some research on the types of issues clients seek counselıng for, there is a lack of studies prioritizing these needs in relation to the preparation of mental health professionals 
Simılarly, it could be helpful to learn more about the kinds of experiences directors value when hiring mental health professionals For example, how would directors rate experiences workıng in a community college counselıng center against experience workıng in an inpatient psychiatric facility? These data could be important in helping training programs improve the relevancy of internship experiences for those intending to work in college and university counselıng centers

An additional important area for future research would be related to researching different models of distributıng roles withın college and university counselıng centers Many directors appeared to perceive all staff as needing to be advanced clinicians able to handle a diverse range of complex mental health needs However, a few appeared more open for less capable staff referring clients to other staff members or to outside agencies when encounterıng clients with needs outside of their competency Moreover, one expert reviewer challenged the idea of comparıng varıous credentials of mental health professions, because it was his position that professionals of different credentials serve different roles Thus, research is needed to further illuminate the models of role distributions currently used and to evaluate the strengths and weakness of different models

\section{Summary}

The adequacy of preparation of master's level counselors for work in college and university counselıng centers was assessed through survey research about the capabilities of entry-level master's level counselors Results indicated that counselors were found capable in all areas except supervision, but were overall rated lower than doctoral degree mental health professionals The study was unable to account for differences in ratıngs of 
counselors based on director traits and institutional factors The results may help counselors workıng or interested in workıng in college and university counselıng centers obtain additional training and experience in areas viewed that they are viewed as less capable The results of this study may help counselor educators identify areas to improve trainıng based on items rated less favorably by directors, and provide feedback on current trainıng standards Future research is recommended to further explore the relative importance of roles fulfilled by clinicians and client needs served in college and university counseling centers, and to further evaluate the preparation of master's level counselors for work in this settıng 


\title{
CHAPTER SIX
}

\section{MANUSCRIPT}

THE PREPARATION OF MASTER'S LEVEL PROFESSIONAL COUNSELORS FOR POSITIONS IN COLLEGE AND UNIVERSITY COUNSELING CENTERS

\author{
Brian M Shaw \\ Theodore P Remley, Jr \\ Christine Ward \\ Old Domınıon University
}

To be submitted to the

Journal of College Counseling 


\begin{abstract}
This study investigated college and unıversity counselıng center directors' perceptions of the adequacy of preparation of master's level counselors for work in college and university counselıng centers Results indicated that counselors were rated on average as prepared, but that many directors had concerns about their ability to work with more severe mental health issues Findings are discussed, and implications for trainıng and preparation of college counseling practitioners is presented
\end{abstract}




\section{INTRODUCTION}

In recent years, college and university counseling centers have emerged as increasingly complex settıngs for mental health professionals to practice College counselors are often required to serve a multitude of functions including providing counselıng and crisis intervention to students experiencing problems, conducting preventative outreach programming to the campus community, consultıng with faculty and staff, conductıng research and program evaluation, and providıng trainıng and supervision of interns and junior staff (Boyd et al , 2003, Counsel for Advancement of Standards in Higher Education, 2009, DeStefano, Petersen, Skwerer, \& Bickel, 2001, Gallagher, 2009)

In additıon, college counselors must serve an increasingly diverse study body facing a multitude of concerns Examples of diversity include racial and cultural minorities, international students, nontraditional students, and openly gay and lesbian students (Chang, 1999) Recent studies reflect an increase in minorities, students over the age of 25, and international students (Choy, 2002, Institute of International Education, 2006) In light of this increase in diversity, counselors in these settings are being called upon to be more multiculturally sensitive, and to adjust services such that they are relevant and accessible to a demographically changing student population (e g, Benshoff \& Bundy, 2000, Bishop, 1990, Hodges, 2001, Stone \& Archer, 1990, Wright, 2000) Regardıng presentıng concerns, counselors may provide services for a variety of personal, academıc, and career concerns (Pace, Stamler, Yarrıs, \& June, 1996, Stone \& Archer, 1990, Whiteley, Mahaffey, \& Geer, 1987) Moreover, significant attention has been raised related to the apparent increase in the severity of mental health issues of 
students (B1shop, 2006, Sharkın \& Coulter, 2005) An often-cited source of supportıng evidence of this increase is an annual survey of college and university counseling center directors (Gallagher, 2009) that has consistently reported a perception of the increase in severity of client problems

There are also multıple legal and ethical challenges that college counselors face Two primary areas where challenges have been noted are in balancing emerging demands against adminstratıve and budgetary constraints, and managing the conflicts of multiple roles and allegiances that counselors serve within the institution (Bishop, 2006, Davenport, 2009) Admınıstrative and budgetary pressures compel counselors to make difficult decisions regarding client care at the same tıme as demand for services is rising Counselıng centers have responded by limitıng sessions of students, implementing wait lists, and referrıng some students to community resources outside of the college or university (Bishop, 2006, Stone \& Archer, 1990) Each of these responses may create ethical and legal dilemmas for counselıng center staff Related to conflıctıng roles, mental health professionals in college counseling settıngs have been referred to as double-agents (Szasz, 1967), serving both students and adminıstrators In relation to students, counselors bulld alliances with students to help them face concerns and issues that may relate to professors and the institution At the same time, counseling centers may provide consultation to faculty and staff regardıng problem students, and accept mandated referrals (Francis, 2000) These competıng allegıances have become more complex after the mass tragedies on campuses, such as the 2007 shootıngs at Virgınıa Tech In the wake of these events, there has been an increased pressure on college and university counseling centers to serve as homicidal prevention gatekeepers, with a focus on providing 
additional attention to screening for clients who may pose a risk to others on campus (Davenport, 2009, p 182)

The American Counseling Association Code of Ethics (ACA, 2005) exhorts counselors to "practice only within the boundaries of their competence, based on their education, trainıng, supervised experience, state and national professional credentials, and appropriate professional experience" (p 9) Furthermore counselors working in specialty areas are supposed to obtain "appropriate education, training, and supervised experienced" ( $\mathrm{p}$ 9) related to that settıng The Council for Accreditation of Counselıng and Related Educational Programs (CACREP, 2009) has recognized college and university counseling as a specialty area that has unıque trainıng needs that vary from other areas of counseling Thus, it is important for counselors working in college counseling settıngs to ensure that they are adequately prepared

This quantitatıve research study assessed the adequacy of preparation of master's level counselors for work in college and university counselıng centers by examınıng college and university counseling centers directors' ratıngs of the capabilities of entrylevel master's level counselors For purposes of this study, master's level counselor referred to a mental health professional with a master's degree in counseling Preparation was assessed by examınıng college and university counselıng center directors' ratıngs of the capabilities of entry-level master's level counselors to meet the needs of clients seekıng services and perform duties associated with the work of counselors in this settıng The directors' overall assessment of preparation and the mean value of scores from ratings of specific areas were the dependent variables of the study The independent variables in the study were the credentials of the counseling center director, the number 
of years he or she had been a mental health professional, the number of years he or she had been a director, the size of the college or university, the number of full time mental health professionals employed by the counseling center, whether or not the counseling center employed at least one professional counselor, and whether the institution was public or private

The primary research questıon of this study was How do college and university counseling center directors rate the adequacy of preparation of entry-level master's level counselors for work as mental health professionals within their centers? This question was explored by the sub-questıons (1) How do directors' overall ratıngs of entry-level master's level counselors compare to overall ratıngs for other entry-level mental health professionals in simılar positions? and (2) How do directors rate the ability of entry-level master's level counselors to meet the needs of clients and perform specific tasks associated with mental health professionals in a college or university counseling center? Additıonally, this research project sought to answer the question To what extent do the credentials of the counseling center director, the number of years he or she has been a mental health professional, the number of years he or she has been a director, the size of the college or university, the number of full time mental health professionals employed by the counselıng center, whether or not the counseling center employs at least one professional counselor, and whether tne institution is public or private predict perceptions of the ability of entry-level master's level counselors for work in college and university counselıng centers? 


\section{METHOD}

\section{Participants}

The population used for the study was directors of counselıng centers at 4-year colleges and universities located in the U S which offer on-campus housing and have at least 1,000 students enrolled Colleges and universities without on-campus housing and those with less than 1,000 students were excluded based on the assumption that counselıng services at those institutions would be significantly different in scope

A list of colleges and universities in the U S was obtained by accessing an online database of the Natıonal Center for Education Statistics (NCES, 2009), a part of the U S Department of Education A search of 4-year institutions in the U S that grant bachelor's degrees resulted in 2,467 institutions (NCES, 2009) This number closely matched the number of 4-year higher education institutes, 2,582, reported by the U S Census Bureau (2009) Elıminating colleges and universities without on-campus housing or with less than 1,000 enrolled students reduced the list to 1,325 institutions An attempt was made to obtain email addresses for each director by searching the respective institution's web site and by contactıng the counselıng center and requesting the emall address by phone Institutions that did not report having a counseling center, that refused to provide an emall address, or whose email was returned undeliverable, were excluded from the list of participants An initial pilot survey was submitted to 50 directors randomly selected from the population who were also excluded from the full study These exclusions reduced the list of participants solicited in the full study to 1,114

A total of 157 directors participated in the study, representing a completion rate of $141 \%$ The number of partıcipants met the minımum requirement for a medium effect 
s1ze based on the statistical analysis methods used (Cohen, 1992) Of the 157 participants, $592 \%(n=93)$ were women Partıcıpants had an average of 197 years experience $(S D=$ 10) in mental health and 91 years of experience as a college or university counseling center director $(S D=8)$ Regardıng credentials, the majority of directors were clınical or counselıng psychologists (44\%), followed by professional counselors ( $312 \%)$, social workers (15 3\%), marriage and family therapists (7 6\%), and nurses (45\%) Of the participants, $962 \%$ indicated that they had some experience workıng with master's level counselors including being responsible for hirıng counselors, workıng as a clınıcal or admınıstrator supervisor of a counselor, or workıng as a colleague of a counselor

Institutions from 41 states were represented in the study, and included a range of small (less than 2,500) and larger institutions (greater than 20,000) Approximately three quarters of the participants were from schools with 10,000 or less students enrolled The majority of partıcipants (57 3\%) worked for private institutions, with $396 \%$ indicatıng the institution was religiously affiliated Directors reported employing a range of mental health professionals including psychiatrısts, clinical psychologists, counselor psychologists, master's and doctoral level professional counselors, master's and doctoral level clinical social workers, master's and doctoral level marriage and family therapists, and rehabilitation counselors Counseling centers had the highest mean number of master's level counselors employed $(M=148, S D=190)$, followed by clinical psychologists $(M=115, S D=261)$ and counselıng psychologists $(M=100, S D=$ 226) 


\section{Procedure}

The study was conducted onlıne usıng a web-based survey Email messages were sent to counseling center directors providing a request for the recipıent to participate in the research along with a hyperlink to the onlıne survey web site A follow up email was sent approximately 3 weeks after the initial email

\section{Instrument}

The survey instrument collected demographic and counseling center information, deta1led ratıngs of entry-level master's level counselors ability to perform tasks and meet client needs, overall ratıngs of different mental health professionals' preparation, and open response comments of partıcıpants' perceptıons of master's level counselor preparation

Demographic and Counselıng Center Information. Demographic information was collected on the director's gender, mental health credentıals, the highest educational degree obtained, the number of years of experience as a mental health professional, and the number of years the director had been employed as a college or university counselıng center director Information on the counseling center included the number of mental health professionals employed, the size of the college or university served by the center, whether the institution was public or private, and the state where the institution was located

Ratıng of Entry-Level Master's level Counselors Abılity to Perform Specific Tasks and Meet Client Needs. Items were created based on a review of literature, a review of exıstıng standards for college and university counselıng centers, and personal experıences workıng in a unıversity counselıng center Items were categorızed as either 
representıng a common task that a counselor would be expected to perform or a specific need of clients Partıcipants were asked to rate each item using a 6-point Likert scale $(1=$ very unprepared, $6=$ very prepared) Higher scores indicated a higher level of perceived abilities of counselors to complete tasks or meet client needs in a particular area

\section{Overall Rating of Entry-Level Master's level Counselors and Other Mental}

Health Professionals. The survey instrument asked participants to rate professional counselors, clinical social workers, marriage and family therapists, clinical psychologists, counselıng psychologists, psychiatrists, and rehabilitation counselors each on a 6-point Likert scale $(1=$ very unprepared, 6 = very prepared $)$, based on their perception of the adequacy of preparation of each type of mental health professional for work in college and university counseling centers

Expert Review and Pilot Study. For establishing valıdity, the initial list of items was sent to an expert panel of college educators with expertıse in college and university counseling Based on feedback from experts, ttems were added or modified in the instrument Following the expert review, a pilot study was conducted with 50 partıcipants Seven instruments were completed for a completion rate of $14 \%$ Item analysis was conducted on the 31 items of the instrument All 1tems had correlations greater than 50 except for one 1tem "Outreach" $(r=17)$ However, based on the low number of completed instruments in the analysis and a lack of a content difference between outreach and other items in the instrument, it was determined to leave the item in the instrument The coefficient alpha for the 31 items was 98 


\section{Data Analysis}

Following data collection, an item analysıs and an exploratory factor analysis using principal component extraction and an oblique rotation were conducted to determine core factors present in the instrument and to verify that the items in the instrument were appropriate for the purposes of this study The item analysis was conducted on the 31 items ratıng master's level counselors utılizıng the data from the full study All items had correlations greater than 40 , and the coefficient alpha for the 31 1tems was 96 The Kaiser-Meyer-Olkın (KMO) measure of sampling adequacy was 92, indicatıng the sample was adequate for factor analysis Barlett's test of sphericity was significant $(p<001)$ and thus rejected the null hypothesis of lack of sufficient correlation between the variables A scree plot suggested 3 factors would be used in the solution representing $6164 \%$ of the variance

A review of the initial solution revealed that all communalities were greater than 5 except for Supervision, which had a value of 36 Because this item was exceptionally low, it was removed from the model and the factor analysis was rerun The final model had 30 items and a KMO value of 93 The rotated solution indicated three factors high risk counselıng, low risk counselıng, and indirect duties These factors represented $6368 \%$ of the variance Communalities for the 30 items ranged between 49 and 79 Based on these findings three new variables were created representıng the total of items in each factor high risk counselıng, low risk counselıng, and indirect dutıes Complexly determined 1tems were added to the factor that they loaded the highest on Results from the item analysis and factor analysis supported the appropriateness of items included in the instrument for purpose of this study 
Following the analysis of the instrument, descriptive and frequency statıstics were used to evaluate detalled ratings of master's level counselors, and to compare overall ratıngs of master's level counselors to ratıngs of other mental health professionals Multiple regression analyses were then conducted to predict the score on identified factors (e g high risk counseling, low risk counseling, and indirect duties) from the credentials of the director, the director's years of experience as a mental health professional, the director's years of expenence as director, the size of the college or university, the number of full time mental health professionals employed by the counselıng center, whether the counseling center employed at least on professional counselor, and whether the institution was private or public The models generated were used to examıne the relationship between predictor variables and the scores on identıfied factors obtained from evaluatıng the perceptions of capabilities of entry-level master's level counselors to perform tasks and meet client needs associated with work in college and university counseling centers The analyses reported on the percentage of variability in the ratıngs based on these predictors, and on which percentages were statıstıcally significant

\section{RESULTS}

\section{Comparison of Overall Scores}

Results from overall ratıngs indicated that $752 \%$ of participants somewhat or moderately agreed that entry-level master's level counselors were overall prepared to meet client needs and conduct associated tasks of mental health professionals in a college or university counseling center For purposes of comparing ratıngs, a numeric value was assigned to each of the Likert-scale values, beginning with a 1 for Strongly Disagree to a 
6 for Strongly Agree Means and standard deviatıons were then calculated for the overall ratıng of each type of professional (see Table 1) Usıng this method, clinical psychologists were rated highest $(M=523, S D=78, N=157)$, and master's level counselors were rated 6 th $(M=468, S D=95, N=157)$ Of note, master's level counselors were rated the highest of master's level professionals

\section{Detarled Ratıngs of Counselors}

Partıcipants rated their perception of the ability of entry-level master's level counselors to meet client needs in a college or unıversity counseling center For purposes of reportıng ratıngs, a numeric value was assigned to each of the Likert-scale values, beginnıng with a 1 for Strongly Disagree to a 6 for Strongly Agree Means and standard deviatıons were then calculated for each ratıng (see Table 2) Counselors were rated highest in their ability to meet client needs related to Relational Difficulties $(M=516$, $S D=82, N=157)$, Self-Concept Issues $(M=509, S D=82, N=157)$, and Mood Related Issues $(M=499, S D=89, n=156)$ Counselors were rated lowest in their ability to meet client needs related to Schızophrenıa and Other Psychotıc Features $(M=354, S D$ $=131, N=157)$, Psychotropic Medicatıons $(M=359, S D=127, n=156)$, and Personality Disorders $(M=371, S D=137, N=157)$

Partıcıpants rated the perceived ability of master's level entry-level counselors to perform specific roles (see Table 3) Counselors were rated highest in their ability to perform Individual Counselıng $(M=525, S D=88, n=156)$, Outreach $(M=496, S D=$ $102, n=156)$, and Administration $(M=495, S D=115, n=156)$ Counselors were rated lowest in their ability to perform Supervision $(M=288, S D=142, n=155)$, 
Consultation $(M=406, S D=122, N=157)$, and Assessment and Diagnosis $(M=414$, $S D=119, n=156)$

\section{Multıple Regression Analysis}

Multiple regression analyses were used to explore factors that may have influenced directors' ratıngs of counselors Predictors were the credentials of the counseling center director, the number of years he or she had been a mental health professional, the number of years he or she had been a director, the size of the college or university, the number of full time mental health professionals in the counseling center, whether the counselıng center employed at least one professional counselor, and whether the institution was public or private Three multiple regression analyses were run using the factor score for high risk counseling, low risk counseling, or indirect duttes as the dependent variable

None of the regression analysis models were significant The results of the first analysıs indicated that the overall model did not significantly predict high risk counseling, $R^{2}=13, F(13,128)=149, p=13$ The results of the second analysis indicated that the overall model did not significantly predict low risk counselıng, $R^{2}=$ $07, F(13,130)=78, p=66$ The results of the third analysis indicated that the overall model did statıstically predict indirect dutıes, $R^{2}=15, F(13,130)=173, p=06$

\section{DISCUSSION}

Finding from this study indicate that entry-level master's level counselors are generally viewed as prepared for work in college and university counseling centers in all areas except for supervision, with marginal concerns related to identifying, helping or referring clients related to personality disorders, psychotropic medicatıons, and 
schizophrenia and other psychotic features The low ratıng of supervision was not surprising considering supervision is not a core part of master's level counselor training standards and in some states supervision requires additional coursework and experience beyond a master's degree (Bernard \& Goodyear, 2009, CACREP, 2009)

Despite positive ratıngs, entry-level master's level counselors were rated overall below entry-level counselıng psychologists, clınıcal psychologist, doctoral level counselors, doctoral level social workers, and psychiatrısts Negatıve ratıngs and openended responses of some participants further illuminated that these differences were perceived as a concern by some and had an impact on hirıng decisions Some responses suggested that differences in ratıngs could have been partly accounted for by the additıonal experience that doctoral level clinicians have as part of their degree requirement (e g , additional hours required as part of internship and practicum experience in psychology degrees) Other responses noted that there was significant variance in the capabilities of entry-level counselors that was dependent on factors including the program they graduated from, the quality and relevance of the counselor internship experıence, and indıvidual traits including age and life experıences

The results of this study had similarities and differences to similarly structured research of Martın, Partın, and Trivette (1998), who surveyed directors of mental health agencies in Ohıo about their perspectives towards counselors Simılarly, counselors in their study were rated on average qualıfied to meet client needs Results also corresponded with high ratings found in their study of counselors in the areas of individual counseling, administration, and management of ethical and legal ıssues Also, Martın, Partın, and Trivette (1998) sımılarly reported directors' perceptions of counselors 
being less skilled in the areas of supervision, psychotropic medication, and psychopathology

However, in overall ratıngs Martın, Partın, and Trıvette (1998) found clınıcal social workers were rated the highest overall, followed by psychıatrısts, psychologists, and then professional counselors In contrast, in this study, psychologists were rated the highest, with social workers rated lower than psychiatrists and counselors Differences in findıngs may be accounted for in part by different demands and client needs between community mental health centers versus college and university counseling centers Other differences include that Martın, Partın, and Trıvette's study was focused on evaluatıng all licensed mental health professionals as opposed to only entry-level mental health professionals and their study was specific to mental health professionals in Ohio Moreover, Martın, Partın, and Trivette hypothesızed that the fact that most of the directors in their study were clinical social workers may have biased ratings of clinical social workers

The lack of statıstical significance of the regression model with the counseling center director's credentıals as a predictor contrasted with with Martın, Partın, and Trivette's (1998) study that found counselors were rated lower by clinical social workers than by other counselors Martın, Partın, and Trivette suggested that the results of their study might represent the preference of directors for clinıcians with similar credentials Given that psychologists were represented in the greatest number in this study, one might have expected a statıstically significant difference in ratıngs of counselors by psychologists In the results, whether the director was a counseling psychologist contributed significantly to the models for predicting scores on counselors' ability to 
perform indirect duties and respond to high risk client needs However, the models themselves were not found to be statistically significant

Additionally, Destefano, Petersen, Skwerer, and Bıckel's (2001) study found differences among the importance directors gave to various roles of counselors based on the years of experience of the director, the size of the institution, and whether the institution was public or private Vespia (2007) also found differences between small and large institutions in staffing and in practices of assessment, diagnosis, and treatment However, in this study these differences were not significant predictors of ratıngs of the ability of entry-level master's level counselors

\section{Implications for College Counseling}

Previous studies have shown college and university counselıng centers as predominantly staffed by doctoral level clınıcians (Gallagher, 2009, Stone, Vespia, \& Kanz, 2000) Stone, Vespia, and Kanz (2000) found 94\% of counselıng center staff members had a doctoral degree in counselıng psychology or clinical psychology An annual survey of college and university counselıng center directors (Gallagher, 2009) has also reflected the predominant employment of doctoral level psychologists as directors As more master's level counselors are traned for work in college and university counseling centers it is important that they are adequately prepared Given the increasing ımportance being given to college and university counselors handlıng more severe mental health concerns (e g , Bishop, 2006, Gallagher, 2009, Kitzrow, 2003), perceived deficiencies noted in this study related to these areas would warrant attention Thus, master's level counselors workıng or desırıng to work in college or university counselıng 
centers would likely benefit from additıonal trainıng and expenence related to more severe mental health concerns

Additionally, while the findings that entry-level counselors were rated on average as capable in almost all areas surveyed, many directors were more critical of the preparation of counselors Entry-level master's level counselors seekıng work in centers with directors of simılar opinions may face difficulties being hired, if not being excluded entırely from the hirıng pool However, by and large directors expressed that they felt master's level counselors would close any perceived gap in preparation with additional experience and supervision In this way, hirıng concerns may relate primarily to candidates without any prior counselıng experience

For counselor trainees intending to work in college or university counselıng centers, one way of mitigatıng concerns of more critical directors would be through obtainıng practıcum and internship experiences related to college counselıng Also, counselors unable to find immediate work in college or university counseling positions upon graduatıng may have to seek out "bridge positions" that will gain them additional experience and supervision to advance their clınical skills Additionally, master's level counselors may want to consider further trainıng and experience through a doctoral degree in Counselıng or Counselor Education Many directors noted that the doctoral degree provides additional job opportunities and helps mental health professionals practicing in higher education settıngs have greater credibility with admınıstrators, students, and faculty Addıtıonally, CACREP (2009) standards include traınıng in supervision as part of the doctoral degree requirement, which was an area where entrylevel counselors were noted as lackıng preparatıon 


\section{Limitatıons and Areas of Future Research}

Limitations exist in this study that should be considered in the interpretation of results These limitations relate to the instrument and the sample used As an exploratory study the instrument utilized in the study was created specifically for this study While steps were taken to review the validity of the instrument, its novelty increases the possibility that items were not representative of the requirements of counselors in college and university counselıng centers Additionally, the instrument did not weight the importance of items Thus, ratıngs of potentially less important areas may distort conclusions on the overall preparation of counselors Similarly, some issues may be more or less important based on institutional characterıstics, which may limit generalizations to some college and university counselıng centers Future research could assess the importance that directors attach to the ability of mental health professionals to perform specific roles and meet specific needs

Additionally, this study makes an inference on preparation based on an assessment of capabilities As many participants noted in comments, the capabilities of counselors may be related substantially to individual factors that do not reflect on the quality of the training program the counselor attended This variance due to individual factors may limit the ability to extract from data broader implications about counselor preparation for college and university counselıng centers

\section{Sampling limitations}

Related to sampling limitations, a relatıvely low percentage of the population surveyed completed the instrument, which may affect generalizability Moreover, the 
small number of participants reduced the power of predictor variables in the analyses, potentrally preventıng the identificatıons of factors that may have influenced ratıngs Additionally, partıcipants self-selected to complete the study, thus differences may have existed between directors that completed the instrument and those that did not Moreover, since the study did not require a minımum amount of experience with master's level counselors to complete the instrument, results may be skewed by perceptions that do not accurately reflect on the actual capabilities of counselors Simılarly, participants may have responded to the survey instrument based on older experiences, not reflective of current standards of training Future research could help mitigate some of these limitations through assessing preparation from other perspectives, such as from the viewpoint of master's level counselors who currently work in college counselıng settıngs 
Table 1

Descriptive Statıstics for Overall Rating of Mental Health Professionals

\begin{tabular}{lccccc}
\hline Credential & Min & Max & Mean & SD & $n$ \\
\hline Counselıng Psychologist & 3 & 6 & 536 & 69 & 155 \\
Clinical Psychologist & 2 & 6 & 523 & 78 & 157 \\
Doctoral Level Counselor & 2 & 6 & 512 & 78 & 155 \\
$\begin{array}{l}\text { Doctoral Level Social Worker } \\
\text { Psychiatrist }\end{array}$ & 2 & 6 & 492 & 89 & 154 \\
$\begin{array}{l}\text { Master's Level Counselor } \\
\text { Master's Level Social Worker }\end{array}$ & 1 & 6 & 483 & 102 & 156 \\
$\begin{array}{l}\text { Doctoral Level Marriage and Family } \\
\text { Therapist }\end{array}$ & 1 & 6 & 455 & 95 & 157 \\
$\begin{array}{l}\text { Master's Level Marriage and Family } \\
\text { Therapist }\end{array}$ & 1 & 6 & 424 & 111 & 155 \\
$\begin{array}{l}\text { Master's Level Rehabılitation } \\
\text { Counselor }\end{array}$ & 1 & 6 & 375 & 122 & 155 \\
\hline
\end{tabular}




\section{Table 2}

Ratings of Entry-Level Master's Level Counselors Ablltty to Meet Client Needs

\begin{tabular}{|c|c|c|c|}
\hline Client Need & Mean & $S D$ & $n$ \\
\hline Relational Difficulties & 516 & 82 & 157 \\
\hline Self-Concept Issues & 509 & 82 & 157 \\
\hline Mood Related Issues & 499 & 89 & 156 \\
\hline Learning/Academic Concerns & 490 & 94 & 156 \\
\hline Stress, Anxiety, and Phobias & 490 & 90 & 156 \\
\hline Career Related Issues & 477 & 104 & 157 \\
\hline Anger Issues & 469 & 95 & 156 \\
\hline Special Student Populations & 469 & 97 & 157 \\
\hline Sulcidal Ideation or Attempts & 441 & 115 & 157 \\
\hline Sexual Identity Issues & 438 & 111 & 157 \\
\hline Substance Abuse and & 420 & 111 & 157 \\
\hline \multicolumn{4}{|l|}{ Addıctıve/Compulsıve Behaviors } \\
\hline Self-Injury Behaviors & 417 & 113 & 157 \\
\hline Risk of Harm to Others & 404 & 127 & 155 \\
\hline Trauma Related Issues & 404 & 137 & 156 \\
\hline Eatıng Related Issues & 400 & 116 & 157 \\
\hline Personality Disorders & 371 & 137 & 157 \\
\hline Psychotropıc Medicatıons & 359 & 127 & 156 \\
\hline Schizophrenıa and Other Psychotıc & 354 & 131 & 157 \\
\hline Features & & & \\
\hline
\end{tabular}


Table 3

Ratıng of Entry-level Master's Level Counselors Ablltty to Perform Roles

\begin{tabular}{|c|c|c|c|}
\hline Role & Mean & $S D$ & $n$ \\
\hline Individual Counselıng & 525 & 88 & 156 \\
\hline Outreach & 496 & 102 & 156 \\
\hline Administration & 495 & 115 & 156 \\
\hline Referrals & 474 & 107 & 157 \\
\hline Management of Ethical and & 472 & 111 & 157 \\
\hline \multicolumn{4}{|l|}{ Legal } \\
\hline \multicolumn{4}{|l|}{ Issues/Risks } \\
\hline Group Counselıng & 466 & 116 & 156 \\
\hline Utılızıng Research & 461 & 113 & 157 \\
\hline Crisis Intervention & 431 & 119 & 155 \\
\hline Couples and Family Counselıng & 423 & 121 & 155 \\
\hline Conductıng Research and & 421 & 130 & 157 \\
\hline \multicolumn{4}{|l|}{ Evaluation } \\
\hline Assessment and Diagnosis & 414 & 119 & 156 \\
\hline Consultation & 406 & 122 & 157 \\
\hline Supervision & 288 & 142 & 155 \\
\hline
\end{tabular}




\section{REFERENCES FOR CHAPTER SIX}

American Counselıng Association (ACA) (2005) ACA code of ethics Alexandria, VA Author

Benshoff, J M , \& Bundy, A P (2000) Nontraditıonal college students In D C Davis \& K M Humphrey (Eds), College counselıng Issues and strategies for a new millennium (pp 133-151) Alexandria, VA American Counselıng Association

Bernard, J M , \& Goodyear, R K (2009) Fundamentals of clinical supervision Upper Saddle River, NJ Pearson Education

Bishop, J B (1990) The university counselıng center An agenda for the 1990s Journal of Counseling \& Development, 68, 408-413

Bıshop, J B (2006) College and university counseling centers Questions in search of answers Journal of College Counseling, 9, 9-19

Boyd, V , Hattauer, E , Brandel, I W , Buckles, N, Davıdshofer, C , Deakın, S , Steel, C M (2003) Accreditation standards for university and college counselıng centers Journal of Counseling \& Development, 81, 168-177

Chang, M J (1999) Does racial diversity matter? The educational impact of a racially diverse undergraduate population Journal of College Student Development, 40, $377-395$

Choy, S (2002) Access and persistence Findings from 10 years of longitudinal research on students Washington, DC American Council on Education

Cohen, J (1992) A power primer Psychological Bulletın, 112(1), 155-159

Councl for Accreditation of Counselıng and Related Educational Programs (2009) The CACREP standards Alexandria, VA Author 
Davenport, R (2009) From college counselor to "risk manager" The evolving nature of college counseling on today's campuses Journal of American College Health 58, 181-183 do1 10 1080/07448480903221244

DeStefano, T J , Petersen, J, Skwerer, L , \& Bickel, S (2001, March) Key stakeholder perceptions of the role and functions of college counseling centers Paper presented at the Annual Conference of the National Association of Student Personnel Administrators, Seattle, WA

Francıs, P C (2000) Practıcıng ethically as a college counselor In D C Davis \& K M Humphrey (Eds), College counselıng Issues and strategies for a new millennium (pp 71-86) Alexandria, VA American Counselıng Association

Gallagher, R P (2009) Natıonal survey of counseling center directors Alexandria, VA International Association of Counselıng Services

Hodges, S (2001) Unıversity counselıng centers at the twenty-first century Lookıng forward, lookıng back Journal of College Counselıng, 4(2), 161

Institute of International Education (2006) Open Doors New York Author

Kitzrow, M A (2003) The mental health needs of today's college students Challenges and recommendations NASPA Journal, 41(1), 165-179

Natıonal Center for Educational Statıstıcs (2009) Institutional data retrieved November 25, 2009 from College Navigator database, http //nces ed gov/collegenavigator/ Martın, R , Partın, R , \& Trivette, P (1998) Mental health agency directors' acceptance and perceptions of Licensed Professional Counselors Journal of Mental Health Counseling, 20(3), 227-237 
Pace, D , Stamler, V L , Yarris, E , \& June, L (1996) Roundıng out the cube Evolution to a global model for counseling centers Journal of Counseling and Development, 74, 321-325

Sharkın, B S , \& Coulter, L P (2005) Empırically supportıng the increasing severity of college counseling center client problems Why is it so challenging? Journal of College Counseling, 8, 165-171

Stone, G L , \& Archer, J , Jr (1990) College and university counselıng centers in the 1990s Challenges and limits The Counseling Psychologist, 18, 539-607 do1 $101177 / 0011000090184001$

Stone, G , Vespia, K, and Kanz, J (2000) How good is mental health care on college campuses? Journal of Counseling Psychology, 47, 498-510 do1 10 1037//00220167474498

Szasz, T S (1967) The psychiatrist as double agent Trans-Actıon, 15, 18-24

U S Census Bureau (2009) The 2009 statıstical abstract The natıonal data book Retrieved November 29, 2009 from http //www census gov/compendı/ statab/cats/education/higher_education_summary html

Vespıa, K M (2007) A national survey of small college counselıng centers Successes, 1ssues, and challenges Journal of College Student Psychotherapy, 22, 17-40 do1 10 1300/J035v22n01_03

Whiteley, S M, Mahaffey, P J \& \& Geer, C (1987) The campus counselıng center A profile of staffing patterns and services Journal of College Student Personnel, 28, $71-81$ 
Wright, D J (2000) College counselıng and the needs of multicultural student In D C Davis \& K M Humphrey (Eds), College counseling Issues and strategies for a new mıllennium (pp 153-168) Alexandria, VA American Counselıng Association 


\section{REFERENCES}

American Counselıng Association (ACA) (2005) ACA code of ethics Alexandria, VA Author

American College Counselıng Association (ACCA) (2010) 2009-1010 Community College Counselors Survey Retrieved from http //www collegecounselıng org/ pdf/2009-2010_Community_College_Counselors_Survey_Results pdf

Archer, J, \& Cooper, S (1998) Counselıng and mental health services on campus $A$ handbook of contemporary practices and challenges San Francisco Jossey Bass

Bean J P, \& Metzner, B S (1985) A conceptual model of nontraditional undergraduate student attrition Review of Educational Research, 55, 485-540

Bell, N J , Kanıtkar, K, Kerksıek, K A , Watson, W , Das, A , Kostına-Ritchey, E, Harris, K (2009) It has made college possible for me Feedback on the impact of a university-based center for students in recovery Journal of American College Health, 57(6), 650-658 do1 $102307 / 1170245$

Benshoff, J M , \& Bundy, A P (2000) Nontraditıonal college students In D C Davis \& K M Humphrey (Eds), College counseling Issues and strategies for a new millennium (pp 133-151) Alexandra, VA American Counselıng Association

Benton, S A, Robertson, J M , Tseng, W C, Newton, F B , \& Benton, S L (2003) Changes in counselıng center client problems across 13 years Professional Psychology Research and Practice, 34, 66-72 do1 10 1037//0735-7028 34166

Bernard, J M , \& Goodyear, R K (2009) Fundamentals of clınical supervision Upper Saddle River, NJ Pearson Education 
Bishop, J B (1990) The university counseling center An agenda for the 1990s Journal of Counseling \& Development, 68, 408-413

Bishop, J B (2006) College and university counselıng centers Questions in search of answers Journal of College Counseling, 9, 9-19

Bishop, J B , Gallagher, R P , \& Cohen, D (2000) College students' problems Status, trends, and research In D C Davis \& K M Humphrey (Eds), College counselıng Issues and strategies for a new millennium (pp 89-110) Alexandria, VA American Counselıng Association

Bishop, J B , \& Trembley, E L (1987) Counseling centers and accountability Immovable objects, irresistible forces Journal of Counseling \& Development, 65, 491-494

Boyd, V , Hattauer, E , Brandel, I W , Buckles, N, Davıdshofer, C, Deakın, S , Steel, C M (2003) Accreditation standards for university and college counseling centers Journal of Counseling \& Development, 81, 168-177

Campbell, D , \& Stanley, J (1963) Experimental and quası experımental designs for research Chicago Rand-McNally

Chandler, L A , \& Gallagher, R P (1996) Developıng a taxonomy for problems seen at a university counselıng center Measurement \& Evaluatıon in Counselıng \& Development, 29, 4-12

Chang, M J (1999) Does racial diversity matter? The educational impact of a racially diverse undergraduate populatıon Journal of College Student Development, 40, $377-395$ 
Choy, S (2002) Access and persistence Findings from 10 years of longitudinal research on students Washington, DC American Counc1 on Education

Cohen, J (1992) A power primer Psychological Bulletın, 112(1), 155-159

Cooper, S E , \& Archer, J A , Jr (2002) Evaluation and research in college counselıng center contexts Journal of College Counseling, 5, 50-59

Cornısh, J A , Komınars, K D, Riva, M T, McIntosh, S , \& Henderson, M C (2000) Perceived distress in university counseling center clients across a six-year period Journal of College Student Development, 41, 104-109

Council for Accreditation of Counselıng and Related Educatıonal Programs (2009) The CACREP standards Alexandria, VA Author

Counc1 for the Advancement of Standards in Higher Education (2009) CAS professional standards for higher education (7th ed) Washington, DC Author

Davenport, R (2009) From college counselor to "risk manager" The evolving nature of college counseling on today's campuses Journal of American College Health 58, 181-183 do1 10 1080/07448480903221244

Deroma, V M, Leach, J B , \& Leverett, J P (2009) The relationship between depression and college academic performance College Student Journal, 43, 325334

DeStefano, T J , Mellott, R N , \& Petersen, J D (2001) A prelımınary assessment of the impact of counseling on student adjustment to college Journal of College Counseling, 4, 113

DeStefano, T J , Petersen, J, Skwerer, L , \& Bickel, S (2001, March) Key stakeholder perceptions of the role and functions of college counseling centers Paper 
presented at the Annual Conference of the National Association of Student

Personnel Administrators, Seattle, WA

Draper, M R , Jennings, J , Baron, A , Erdur, O , \& Shankar, L (2002) Time-lımıted counseling outcome in a nationwide college counseling center sample Journal of College Counseling, 5, 26-38

Dusselıer, L , Dunn, B , Yongyı Wang, Shelley II, M C , \& Whalen, D F (2005) Personal, health, academic, and environmental predictors of stress for residence hall students Journal of American College Health, 54(1), 15-24

Farnsworth, D L (1957) Mental health in college and untversity Cambridge, MA Harvard Unıversity Press

Francis, P C (2000) Practıcing ethically as a college counselor In D C Davis \& K M Humphrey (Eds), College counseling Issues and strategies for a new millennium (pp 71-86) Alexandria, VA American Counselıng Association

Gallagher, R P (2001) National survey of counseling center directors Alexandria, VA International Association of Counseling Services

Gallagher, R P (2004) Natıonal survey of counseling center directors Alexandria, VA International Association of Counseling Services

Gallagher, R P (2009) Natıonal survey of counseling center directors Alexandria, VA International Association of Counselıng Services

Ghetie, D (2007) The debate over tıme-lımited treatment in college counselıng centers Journal of College Student Psychotherapy, 22, 41-61

Gibson, J M (2000) Documentation of emotional and mental disabilities The role of the counseling center Journal of College Counselıng, 3, 63-72 
Gilbert, S P (1992) Ethical issues in the treatment of severe psychopathology in university and college counseling centers Journal of Counseling \& Development, $70,695-699$

Grayson, P A , \& Cauley, K (1989) College psychotherapy New York Gullford Press Hayman, P M, \& Covert, J A (1986) Ethical dilemmas in college counselıng centers Journal of Counseling \& Development 64, 318-320

Heitzmann, D (2008) Tragedy at Virginia Tech Trauma and its aftermath The Counseling Psychologist, 36, 479-789

Heppner, P P , \& Neal, G W (1983) Holding up the mirror Research on the roles and functions of counseling centers in higher education Counselıng Psychologist, 11, 81-98 do1 10 1177/0011000083111014

Hınkelman, J M , \& Luzzo, D A (2007) Mental health and career development of college students Journal of Counseling \& Development, 85(2), 143-147

Hodges, S (2001) Unıversity counselıng centers at the twenty-first century Lookıng forward, lookıng back Journal of College Counselıng, 4(2), 161

Hoeppner, B B , Hoeppner, S S , \& Campbell, J F (2009) Examınıng trends in intake rates, client symptoms, hopelessness, and suicidality in a university counselıng center over 12 years Journal of College Student Development, 50(5), 539-550

Institute of International Education (2006) Open Doors New York Author International Association of Counselıng Services (2010) IACS frequently asked questions Retrieved from http //1acsinc org/ Frequently\%20Asked\%20Questions\%20Rev\%204-23-09 html 
Kitzrow, M A (2003) The mental health needs of today's college students Challenges and recommendations NASPA Journal, 41(1), 165-179

Lin, J G (2000) College counseling and international students In D C Davis \& K M Humphrey (Eds), College counseling Issues and strategies for a new millennium (pp 169-183) Alexandria, VA American Counseling Association

Lucas, M S , \& Berkel, L A (2005) Counselıng needs of students who seek help at a university counseling center A closer look at gender and multıcultural issues Journal of College Student Development, 46(3), 251-266 do1 10 1353/csd 20050029

Martın, R , Partın, R , \& Trivette, P (1998) Mental health agency directors' acceptance and perceptions of Licensed Professional Counselors Journal of Mental Health Counselıng, 20(3), 227-237

McGlothlın, J M , \& Davis, T E (2004) Perceıved benefit of CACREP (2001) core curriculum standards Counselor Education and Supervision, 43(4), 274-285

Meadows, M E (2000) The evolution of college counselıng In D C Davis \& K M Humphrey (Eds), College counseling Issues and strategies for a new millennium (pp 15-40) Alexandria, VA American Counselıng Association

Meyers, L S , Gamst, G G , \& Guarıno, A J (2006) Applied multivarıate research Design and interpretation Thousand Oaks, CA Sage

Minamı, T, Davies, D R, Tierney, S C, Bettmann, J E, McAward, S M, Averıll, L A, Wampold, B E (2009) Prelıminary evidence on the effectıveness of psychological treatments delivered at a university counseling center Journal of Counselıng Psychology, 56, 309-320 do1 10 1037/a0015398 
Natıonal Center for Educatıonal Statıstıcs (2009) Institutıonal data retrieved November 25, 2009 from College Navigator database, http //nces ed gov/collegenavigator/ Pace, D, Stamler, V L , Yarrıs, E , \& June, L (1996) Rounding out the cube Evolution to a global model for counselıng centers Journal of Counseling and Development, 74, 321-325

Pledge, D S , Lapan, R T , Heppner, P P, Kıvlıghan, D , \& Roehlke, H J (1998) Stability and severity of presentıng problems at a university counselıng center A 6-year analysis Professional Psychology Research and Practice, 29(4), 386-389 do1 $101037 / 0735-7028294386$

Prescott, H M (2008) College mental health since the early twentieth century Harvard Review of Psychiatry, 16(4), 258-266 do1 10 1080/10673220802277771

Reinhold, J E (1991) The origins and early development of mental health services in American colleges and universities Journal of College Student Psychotherapy, 6, $3-14$

Robertson, J M, Benton, S L , Newton, F B, Downey, R G, Marsh, P A, Benton, S A, Shın, K -H (2006) K-State problem identıfication ratıng scales for college students Measurement and Evaluatıon in Counseling and Development 39, 141160

Sharf, R S (1989) Have the presenting problems of clients at university counseling centers increased in severity? NASPA Journal, 27, 141-146

Sharkın, B S (2004) Assessing changes in categories but not severity of counselıng center clients' problems across 13 years Comment on Benton, Robertson, Tseng, 
Newton, and Benton (2003) Professional Psychology Research and Practice, $35,313-315$ do1 $101037 / 0735-7028353313$

Sharkın, B S , \& Coulter, L P (2005) Empirıcally supportıng the increasing severity of college counseling center client problems Why is it so challenging? Journal of College Counseling, 8, 165-171

Smith, T B, Dean, B , Floyd, S , Sılva, C, Yamashita, M , Durtschı, J \& \& Heaps, R A (2007) Pressing issues in college counseling A survey of American College Counseling Association members Journal of College Counseling, 10, 64-78

Snell, M N , Mallınckrodt, B , Hill, R D , \& Lambert, M J (2001) Predictıng counselıng center clients' response to counselıng A 1-year follow-up Journal of Counseling Psychology, 48, 463-473 do1 10 1037/0022-016748 4463

Stone, G L , \& Archer, J , Jr (1990) College and university counselıng centers in the 1990s Challenges and limits The Counselıng Psychologist, 18, 539-607 do1 10 1177/0011000090184001

Stone, G, Vespia, K, and Kanz, J (2000) How good is mental health care on college campuses? Journal of Counseling Psychology, 47, 498-510 do1 10 1037//00220167474498

Szasz, T S (1967) The psychiatrist as double agent Trans-Actıon, 15, 18-24

U S Census Bureau (2009) The 2009 statistical abstract The nattonal data book Retrieved November 29, 2009 from http //www census gov/compendia /statab/cats/education/higher_education_summary html 
Van Dusen, Willıam R, Jr (2004) FERPA Basic guidelınes for faculty and staff a simple step-by-step approach for compliance Retrieved April 24, 2011 from the NACADA Clearinghouse of Academic Advising Resources Web site http i/www nacada ksu edu/Resources/FERPA-Overview htm

Vermeersch, D A, Whıpple, J L, Lambert, M J, Hawkıns, E J, Burchfield, C M , \& Okı1shı, J C (2004) Outcome questionnaire Is it sensitive to changes in counseling center clients? Journal of Counseling Psychology, 51, 38-49 do1 10 1037/0022-016751 138

Vespia, K M (2007) A national survey of small college counseling centers Successes, 1ssues, and challenges Journal of College Student Psychotherapy, 22, 17-40 do1 10 1300/J035v22n01_03

Vonk, M E, \& Thyer, B A (1999) Evaluatıng the effectıveness of short-term treatment at a university counselıng center Journal of Clinical Psychology, 55, 1095-1106

Whiteley, S M, Mahaffey, P J , \& Geer, C (1987) The campus counselıng center A profile of staffing patterns and services Journal of College Student Personnel, 28, $71-81$

Wilson, S B , Mason, T W , \& Ewing, M J (1997) Evaluatıng the impact of receiving university-based counseling services on student retention Journal of Counselıng Psychology, 44, 316-320 do1 10 1037//0022-0167443316

Wright, D J (2000) College counseling and the needs of multicultural student In D C Davis \& K M Humphrey (Eds), College counseling Issues and strategies for a new millennium (pp 153-168) Alexandria, VA American Counseling Association 


\section{APPENDIX A}

\section{Survey Instrument}

The purpose of this instrument is to evaluate the preparation of master's level counselors for work in university and college counselıng centers by examining the perceptions of counselıng center directors of the capabilities of entry-level master's level counselors.

\section{Section I Experiences Related to Master's Level Counselors}

Indicate the experiences that you have had workung with master's level counselors (select all that apply):

Note: For purposes of this survey instrument, master's level counselor refers to mental health professionals who have a master's degree in counseling and may or may not be licensed.

I have been responsible for, or have served on a committee responsible for hiring master's level counselors

I have worked as an administratıve supervisor of master's level

counselors

I have worked as a clinical supervisor of master's level counselors

I have worked as a colleague of master's level counselors

I have no experience working with master's level counselors

Other (please specify) 


\section{Section II Ratıng of Ability of New Counselors to Meet Client Needs}

On a scale of 1 to 6, rate the following statements based on your experience regardıng the performance of master's level counselors who have just completed their master's degree in counseling. In the event you have not had any experience with new master's level counselors, complete this section based on your beliefs about how they might perform.

$\begin{array}{cccccc}1 & 2 & 3 & 4 & 5 & 6 \\ \text { Strongly } & \text { Moderately } & \text { Somewhat } & \text { Somewhat } & \text { Moderately } & \text { Strongly } \\ \text { Disagree } & \text { Disagree } & \text { Disagree } & \text { Agree } & \text { Agree } & \text { Agree }\end{array}$

1. Relational Difficulties New master's level counselors are capable of helping clients with relational difficulties including difficulties with family, peer, and intımate relationships

$\begin{array}{llllll}1 & 2 & 3 & 4 & 5 & 6 \\ \square & \square & \square & \square & \square & \square\end{array}$

2. Eatmg Related Issues New master's level professional counselors are capable of helping clients with eatıng related concerns including body image issues and eatıng disorders

$\begin{array}{llllll}1 & 2 & 3 & 4 & 5 & 6 \\ \square & \square & \square & \square & \square & \square\end{array}$

3. Substance Abuse and Addictive/Compulsive Behaviors New master's level counselors are capable of assessing, helping, and/or referring clients with substance abuse or addiction/compulsion related issues

4. Suicidal Ideation or Attempts New master's level counselors are capable of assessing, helpıng, and/or referring clients who are experiencing suicidal ideation or have recently made a suicide attempt 
5. Self-ınjury Behaviors New master's level counselors are capable of helping clients with self injury behaviors such as cutting or hair pulling

$\begin{array}{lllllll}1 & 2 & 3 & 4 & 5 & 6\end{array}$

6. Learnıng/Academıc Concerns New master's level counselors are capable of helpıng clients with learning or academic concerns

$\begin{array}{llllll}1 & 2 & 3 & 4 & 5 & 6 \\ \square & \square & \square & \square & \square & \square\end{array}$

7. Mood Related Issues New master's level counselors are capable of helping clients with mood related issues including bereavement, depression symptoms (e g low energy, hopelessness), and mood swings

$\begin{array}{llllll}1 & 2 & 3 & 4 & 5 & 6 \\ \square & \square & \square & \square & \square & \square\end{array}$

8. Stress, Anxiety, and Phobias New master's level counselors are capable of helpıng clients with stress, anxiety, and phobias

$\begin{array}{llllll}1 & 2 & 3 & 4 & 5 & 6 \\ \square & \square & \square & \square & \square & \square\end{array}$

9. Psychotropic Medications: New master's level counselors are capable of understandıng psychotropıc medications their clients might be takıng or might need, and discussing medication issues with clients and their physicians

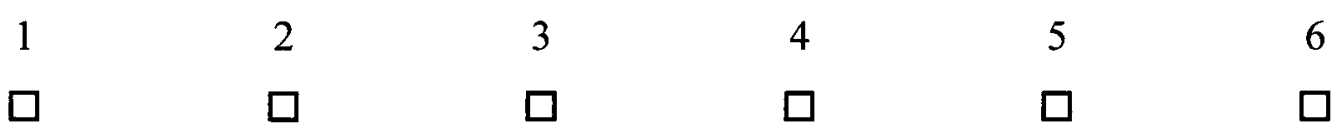

10. Anger Issues New master's level counselors are capable of helping clients with issues related to anger

1

2

3

4

5

6

11. Risk of Harm to Others New master's level counselors are capable of helping clients who have thoughts of violence towards others 
12. Career Related Issues New master's level counselors are capable of helping clients with career related needs including career development and career decision-making
1
2
3
4
5
6

13. Trauma Related Issues New master's level counselors are capable of helping clients with trauma related issues including exposure to violence, exposure to natural disasters, or being the victım of a sexual assault

1

2

2

ロ
3

$\square$
4

5

6

14. Personality Disorders New master's level counselors are capable of identifying, helping, and/or referring clients with a personality disorder as defined by the Diagnostic and Statıstıcal Manual IV Text Revision (DSM-IV-TR)

1 2

3

4

5 6

15. Schizophrenıa and Other Psychotic Features: New master's level counselors are capable of identıfying, helpıng, and/or referring clients exhıbitıng schızophrenia or other psychotic features

16. Sexual Identity Issues New master's level counselors are capable of helping clients with confusion regarding or issues related to one's sexual identity An example would include dealing with concerns related to sexual orientation

17. Self-Concept Issues New master's level counselors are capable of helping clients with confusion regarding or issues related to one's sense of self An example would be clients with low self-esteem 
18. Special Student Populations New master's level counselors are capable of helping racial and cultural minority clients and other special populations

$\begin{array}{llllll}1 & 2 & 3 & 4 & 5 & 6 \\ \square & \square & \square & \square & \square & \square\end{array}$




\section{Section III Ratıng of New Counselors Abılity to Perform Specıfic Roles}

On a scale of 1 to 6, rate the following statements based on your experience regarding the performance of master's level counselors who have just completed their master's degree in counseling. In the event you have not had any experience with new master's level counselors, complete this section based on your beliefs about how they might perform.

$\begin{array}{cccccc}1 & 2 & 3 & 4 & 5 & 6 \\ \text { Strongly } & \text { Moderately } & \text { Somewhat } & \text { Somewhat } & \text { Moderately } & \text { Strongly } \\ \text { Disagree } & \text { Disagree } & \text { Disagree } & \text { Agree } & \text { Agree } & \text { Agree }\end{array}$

1. Individual Counselıng: New master's level counselors are capable of providing individual counseling to clients

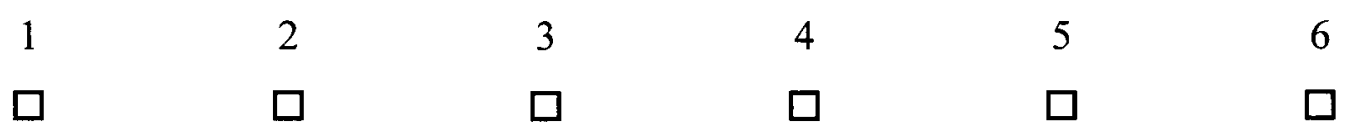

2. Group Counselıng: New master's level counselors are capable of providing group counseling to clients

$\begin{array}{llllll}1 & 2 & 3 & 4 & 5 & 6 \\ \square & \square & \square & \square & \square & \square\end{array}$

3 Couples and Family Counseling New master's level counselors are capable of providing couples and family counseling to clients

1

2

$\square$
4

5 6

4. Consultation: New master's level counselors are capable of providing consultation to university or college faculty, staff, administrators, and paraprofessionals Consultıng would include advocating for changes that have an impact on the learning and mental health environment of the campus and promote student retention
2

3
4 5 
5. Referrals: New master's level counselors are capable of 1dentifying clients whose needs exceed the services offered by the university or college counseling center and referring them to other services within the institution or to other professionals outside of the institution

1

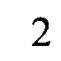

3

4

5

6

6. Assessment and Diagnosis New master's level counselors are capable of providing psychological assessment and diagnosis of clients, including conductıng intakes and assigning a DSM diagnosis

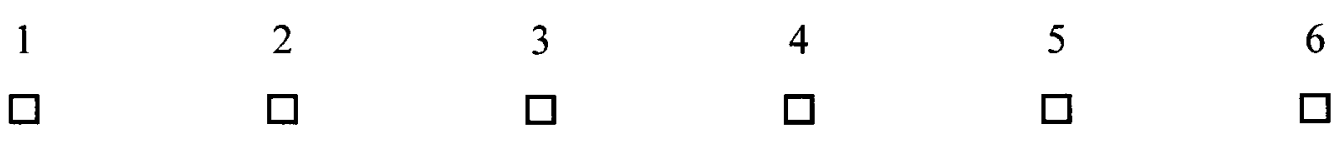

7. Outreach New master's level counselors are capable of designing and delivering outreach programs beneficial to the student community including teaching workshops or classes that act as developmental and preventative interventions
1
2
3
4
5
6

8. Crisis Intervention New master's level counselors are capable of providing crisis intervention including the provision of emergency coverage and response

4

5

6

9. Supervisıon New master's level counselors are capable of providing trainıng and supervision to practicum students, interns, paraprofessionals, and other counselors

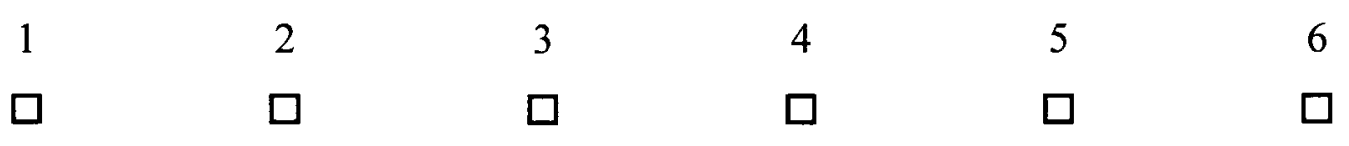

10. Utılızıng Research New master's level counselors are capable of stayıng current on research related to their duties within the counselıng center and utılizing research findings to inform practice 
11. Conductıng Research and Evaluation New master's level counselors are capable of conductıng and partıcıpatıng in research and service evaluatıon actıvitıes

1 2

3

4

5

6

12. Administration New master's level counselors are capable of performing adminıstratıve duties including the mantenance of case records, filing of reports, and completion of other documentation as part of their duties in the counseling center

1

2

3

4

5

13. Management of Ethical and Legal Issues/Risks New master's level counselors are capable of managing ethical and legal responsibilities of working in a university or college settrng 
Section IV Overall Ratıng of Entry-Level Clınıcal Professionals

On a scale of 1 to 6, rate the degree to which you disagree or agree that the following entry-level clinical professionals are overall prepared to meet chent needs and fulfill relevant roles within a college or university counselıng center immediately after completıng their degree programs. In the event you have not had any experience with any of these categories of entry-level clinical professionals, complete this section based on your beliefs about how those professionals might perform.

Note: For purposes of this survey instrument, master's level counselor refers to mental health professionals who have a master's degree in counseling and may or may not be hicensed.

\begin{tabular}{|l|c|c|c|c|c|c|}
\hline $\begin{array}{c}\text { Clmical } \\
\text { Professional }\end{array}$ & $\begin{array}{c}\text { Strongly } \\
\text { Disagree } \\
1\end{array}$ & $\begin{array}{c}\text { Moderately } \\
\text { Disagree } \\
2\end{array}$ & $\begin{array}{c}\text { Somewhat } \\
\text { Disagree } \\
3\end{array}$ & $\begin{array}{c}\text { Somewhat } \\
\text { Agree } \\
4\end{array}$ & $\begin{array}{c}\text { Moderately } \\
\text { Agree } \\
5\end{array}$ & $\begin{array}{c}\text { Strongly } \\
\text { Agree } \\
6\end{array}$ \\
\hline Psychiatrist & $\square$ & $\square$ & $\square$ & $\square$ & $\square$ & $\square$ \\
\hline $\begin{array}{l}\text { Doctoral Level } \\
\text { Clinical } \\
\text { Psychologist }\end{array}$ & $\square$ & $\square$ & $\square$ & $\square$ & $\square$ & $\square$ \\
\hline $\begin{array}{l}\text { Doctoral Level } \\
\text { Counselıng } \\
\text { Psychologists }\end{array}$ & $\square$ & $\square$ & $\square$ & $\square$ & $\square$ & $\square$ \\
\hline $\begin{array}{l}\text { Master's Level } \\
\text { Counselors }\end{array}$ & $\square$ & $\square$ & $\square$ & $\square$ & $\square$ & $\square$ \\
\hline $\begin{array}{l}\text { Doctoral Level } \\
\text { Counselors }\end{array}$ & $\square$ & $\square$ & $\square$ & $\square$ & $\square$ & $\square$ \\
\hline $\begin{array}{l}\text { Master's Level } \\
\text { Social Workers }\end{array}$ & $\square$ & $\square$ & $\square$ & $\square$ & $\square$ & $\square$ \\
\hline
\end{tabular}




\begin{tabular}{|l|c|c|c|c|c|c|}
\hline $\begin{array}{l}\text { Doctoral Level } \\
\text { Social Workers }\end{array}$ & $\square$ & $\square$ & $\square$ & $\square$ & $\square$ & $\square$ \\
\hline $\begin{array}{l}\text { Master's Level } \\
\text { Marriage and } \\
\text { Famıly } \\
\text { Therapists }\end{array}$ & $\square$ & $\square$ & $\square$ & $\square$ & $\square$ & $\square$ \\
\hline $\begin{array}{l}\text { Doctoral Level } \\
\text { Marriage and } \\
\text { Family } \\
\text { Therapists }\end{array}$ & $\square$ & $\square$ & $\square$ & $\square$ & $\square$ & $\square$ \\
\hline $\begin{array}{l}\text { Master's Level } \\
\text { Rehabilitation } \\
\text { Counselor }\end{array}$ & $\square$ & $\square$ & $\square$ & $\square$ & $\square$ & $\square$ \\
\hline $\begin{array}{l}\text { Other } \\
\text { (specify) }\end{array}$ & $\square$ & $\square$ & $\square$ & $\square$ & $\square$ & $\square$ \\
\hline $\begin{array}{l}\text { Other } \\
\text { (specify) }\end{array}$ & $\square$ & $\square$ & $\square$ & $\square$ & $\square$ & $\square$ \\
\hline
\end{tabular}




\section{Section V Personal and Institutional Characterıstics}

Please provide the following information about yourself, your staff, and the institution where you work:

1 What is your gender?

a Male b Female

2 Please check all state licenses that you currently hold from one of more states Psychiatrist Social Worker Counselıng Psychologist Clinical Psychologist Professional Counselor Marriage and Family Therapist Other (please indicate)

3 What is the highest educational degree you have obtained?

4 How many years of experience do you have as a mental health professional?

5 How many years have you been employed as a university or college counselıng center director?

6 What is the approximate student body size of your institution?
a Less than 2,500
b Between 2,500 and 10,000
c Between 10,001 and 20,000
d More than 20,000

7 Indicate the selection that best describes your institution?
a Public
b Private (for-profit)
c Private (not-for-profit)

8 In what state is your institution located? 
9 Indicate the number of each of the following full-tıme clinical professionals that work at the counseling center that you direct

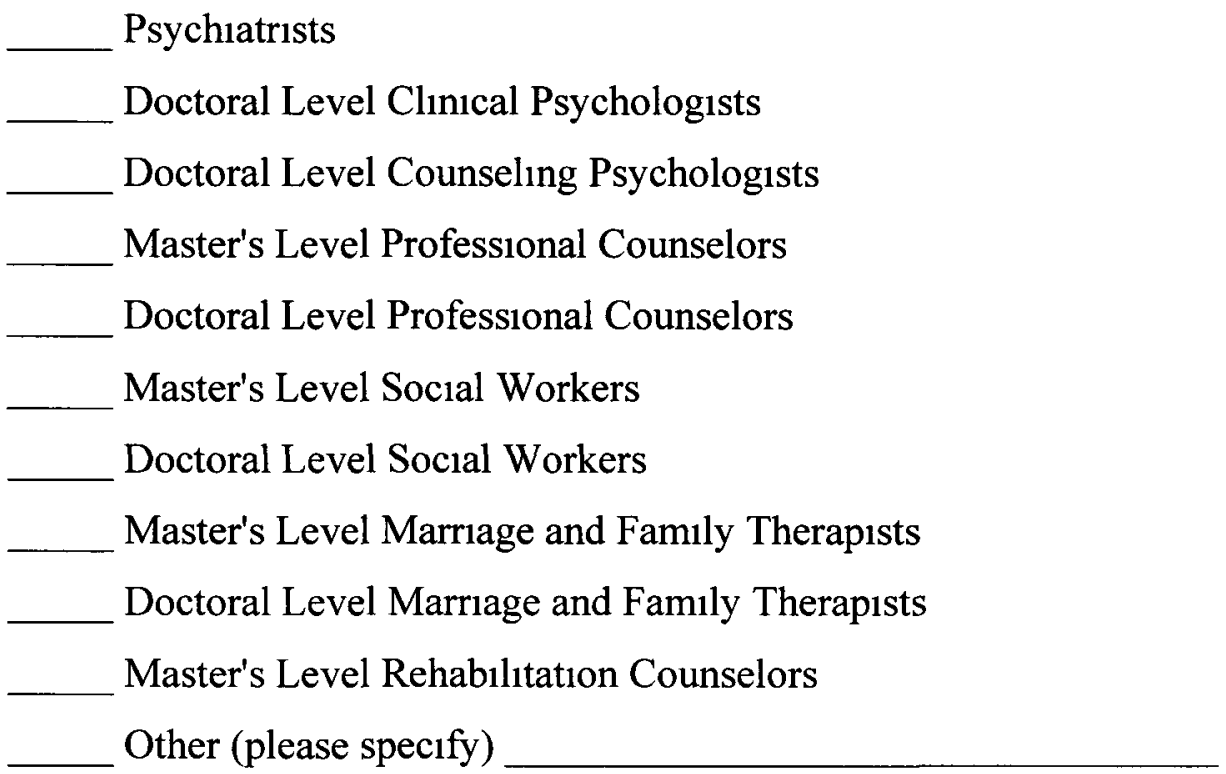

Section VI (Optional) Other Feedback on the Preparation of Counselors

Please indicate here any additıonal comments you have regarding the preparation of new master's level counselors for work in university or college counseling centers.

Note: For purposes of this survey instrument, master's level counselor refers to mental health professionals who have a master's degree in counseling and may or may not be licensed. 


\section{VITA}

Brian M Shaw earned a Bachelor's in Science degree from North Carolına State University in 1997 He earned his Master's of Arts in Counseling from Wake Forest Unıversity in 2008 He is a Natıonally Certıfied Counselor and a Resident in Counselıng workıng towards licensure as a Professıonal Counselor in the state of Vırgınıa

Mr Shaw is a member of several national professional organızations including the American Counseling Association and the American College Counseling Association $\mathrm{He}$ has presented at national and state conferences on topics related to college counselıng, spirituality in counselıng, and legal and ethical issues in counselıng

As a student at Old Dominion University, Mr Shaw was the recipient of the Darden College of Education Doctoral Fellowshıp As a student member of Chı Sigma Iota, Mr Shaw was the chair of the Professional Development Committee and was responsıble for coordınatıng an ongoing serıes of contınuing education workshops presented to the community

Mr Shaw currently works as a staff counselor for the Office of Counseling Services at Old Domınıon Unıversity Prior to enterıng the counselıng field, Mr Shaw worked as a software engineer 